\title{
A (IN)EFICÁCIA DA FORMAÇÃO DOS MAGISTRADOS BRASILEIROS EM DIREITOS HUMANOS E CONTROLE DE CONVENCIONALIDADE
}

\author{
Laborar na proteção dos direitos humanos é \\ como o mito de Sísifo, uma tarefa que não tem \\ fim. É como estar constantemente empurrando \\ uma rocha até 0 alto da montanha, a qual \\ torna a cair e volta a ser empurrada morro \\ acima. Entre avanços e retrocessos, desenvolve- \\ se o trabalho de proteção. Ao descer a \\ montanha para voltar a empurrar a rocha até 0 \\ alto, alcança-se a consciência da condição \\ bumana e da tragédia que a circunda. Mas há \\ que seguir lutando: na realidade, não bá outra \\ alternativa. \\ Juiz Cançado Trindade - CIDH \\ Pueblo Bello vs. Colômbia
}

José Henrique Rodrigues Torres ${ }^{1}$

\section{RESUMO:}

O artigo foi elaborado e desenvolvido com a preocupação de verificar a eficácia da formação de juízas e de juízes brasileiros no campo epistemológico, ético e político, do sistema de proteção dos direitos humanos, no âmbito de uma cultura jurídica conservadora e tradicional, posto que hegemônica, que resiste ao avanço e à consolidação do ethos de uma nova cultura jurídica e política embasada na dignidade humana. Superado o período da ditadura civil militar que se abateu sobre a sociabilidade brasileira a partir de 1964, a Constituição Federal de 1988, empolgada por novos paradigmas democráticos,

\footnotetext{
${ }^{1}$ Pesquisador do Grupo de Estudos em Filosofia e Educação PAIDEIA, Magistrado, Membro do INPPDH.
} 
rompendo com uma cultura excludente, autoritária e impositiva, elegeu a dignidade humana e a preeminência dos direitos humanos como princípios fundamentais e incumbiu aos juízes e juízas a tarefa de garantir esses direitos. Esse foi o objetivo estabelecido pela pesquisa que fundamenta este artigo: investigar se têm sido eficazes os cursos de formação em direitos humanos e controle de convencionalidade ministrados pela ENFAM e, também, pelas Escolas judiciais e de magistratura, estaduais e federais, e, consequentemente, verificar se os magistrados e magistradas estão aplicando as normas de direitos humanos e realizando o controle de convencionalidade, ou seja, se estão garantindo, em sua atividade jurisdicional, a prevalência das normas, regras e princípios do sistema de proteção dos direitos humanos. A pesquisa analisada, em sua vária fase inicial, apresenta o resultado de um estudo sobre as sentenças proferidas por juízes e juízas da Comarca de Campinas, de 2015 a 2019, verificando a abordagem ou referências feitas nessas decisões sobre "direitos humanos" e "controle de convencionalidade". Foram verificadas, pelo sistema de consulta do SAJ, todas as sentenças proferidas em 33 das 38 varas judiciais da Comarca de Campinas. Também são analisados os resultados de outro estudo, abordando "a formação dos juízes e juízas para a proteção dos direitos humanos, a pandemia da Covid 19 e as prisões preventivas", que também evidencia a necessidade da ampliação da formação para o exercício de sua tarefa constitucional de aplicação e garantia da prevalência dos direitos humanos. Finalmente, são ainda apresentados os resultados da análise da evolução da quantidade de processos de réus presos das varas criminais de Campinas, no período de junho de 2019 a junho de 2020, com o objetivo de verificar se ocorreu o "drástico desencarceramento" preconizado pelo sistema de proteção dos direitos humanos. E tudo está a demonstrar que as Escolas judiciais ou de magistratura devem ampliar, intensificar e aprofundar o seu compromisso ético, estético e político de formação dos juízes e juízas para a garantia da prevalência da dignidade humana e império dos direitos humanos em nosso sistema jurisdicional.

Palavras-Chave: Direitos Humanos. Educação. Formação de Magistrados.

\begin{abstract}
:
The article was prepared and developed with the concern of verifying the effectiveness of the training of Brazilian judges in the epistemological, ethical and political field, of the system of protection of human rights, within the scope of a conservative and traditional legal culture, since it is hegemonic, which resists the advance and consolidation of the ethos of a new legal and political culture based on human dignity. Overcoming the period of the military civil dictatorship that fell on Brazilian sociability since 1964, the Federal Constitution of 1988, excited by new democratic paradigms, breaking with an exclusive, authoritarian and imposing culture, elected human dignity and the preeminence of rights human rights as fundamental principles and the task of guaranteeing these rights has been entrusted to the judges. This was the objective established by the research that underlies this article: to investigate whether the human rights and conventionality control training courses taught by ENFAM and also by the state and federal judicial and magistracy schools
\end{abstract}

Filos. e Educ., Campinas, SP, v.12, n.2, p.1085-1125, maio/ago. 2020 - ISSN 1984-9605 
have been effective, and, consequently, to verify whether magistrates and magistrates are applying human rights norms and carrying out the control of conventionality, that is, they are guaranteeing, in their jurisdictional activity, the prevalence of norms, rules and principles of the human rights protection system. The research analyzed, in its various initial stages, presents the result of a study on the sentences handed down by judges and judges from the Campinas District, from 2015 to 2019, verifying the approach or references made in these decisions on "human rights" and "control conventionality". Through the SAJ consultation system, all the sentences handed down in 33 of the 38 judicial courts of the District of Campinas were verified. The results of another study are also analyzed, addressing "the training of judges for the protection of human rights, the Covid 19 pandemic and preventive prisons", which also highlights the need to expand training to exercise their task constitutional enforcement and guarantee of the prevalence of human rights. Finally, the results of the analysis of the evolution of the number of defendants' cases arrested in the criminal courts of Campinas, from June 2019 to June 2020, are also presented, with the objective of verifying whether the "drastic extrication" recommended by the system protection of human rights. And everything is showing that the Judicial or Judiciary Schools must expand, intensify and deepen their ethical, aesthetic and political commitment to training judges to guarantee the prevalence of human dignity and the empire of human rights in our jurisdictional system.

Keywords: Human Rights. Education. Training of Magistrates.

\section{RESUMEN:}

El artículo fue elaborado y desarrollado con la preocupación de verificar la efectividad de la formación de jueces y jueces brasileños en el campo epistemológico, ético y político, del sistema de protección de los derechos humanos, en el ámbito de una cultura jurídica conservadora y tradicional, por ser hegemónica. , que se resiste al avance y consolidación del ethos de una nueva cultura jurídica y política basada en la dignidad humana. Luego del período de la dictadura civil militar que recayó sobre la sociabilidad brasileña desde 1964, la Constitución Federal de 1988, excitada por nuevos paradigmas democráticos, rompiendo con una cultura excluyente, autoritaria e imponente, eligió la dignidad humana y la preeminencia de los derechos. los derechos humanos como principios fundamentales y la tarea de garantizar estos derechos ha sido encomendada a los jueces. Este fue el objetivo establecido por la investigación en la que se basa este artículo: investigar si los cursos de capacitación en derechos humanos y control de convencionalidad impartidos por la ENFAM y también por las escuelas judiciales y de magistratura estatales $y$ federales han sido efectivos y, en consecuencia, Verificar que los magistrados y magistrados estén aplicando estándares de derechos humanos y controlando la convencionalidad, es decir, estén asegurando, en su actividad jurisdiccional, la prevalencia de las normas, reglas y principios del sistema de protección de derechos humanos. La investigación analizada, en sus distintas etapas iniciales, presenta el resultado de un estudio sobre las sentencias dictadas por jueces y jueces del Distrito de Campinas, de 2015 a 2019, verificando el enfoque o 
referencias que se hacen en estas decisiones sobre "derechos humanos" y "control convencionalidad". Todas las sentencias dictadas en 33 de los 38 juzgados del distrito de Campinas fueron verificadas por el sistema de consulta del SAJ. También se analizan los resultados de otro estudio, que aborda "la formación de jueces para la protección de los derechos humanos, la pandemia de Covid 19 y las cárceles preventivas", que también destaca la necesidad de ampliar la formación para el ejercicio de su tarea. aplicación constitucional y garantía de la vigencia de los derechos humanos. Finalmente, también se presentan los resultados del análisis de la evolución del número de casos de imputados detenidos en los juzgados penales de Campinas, de junio de 2019 a junio de 2020, con el objetivo de comprobar si la "drástica extracción" recomendada por el sistema protección de los derechos humanos. Y todo está demostrando que las Escuelas Judicial o Judicial deben ampliar, intensificar y profundizar su compromiso ético, estético y político de formar jueces para garantizar el predominio de la dignidad humana y el imperio de los derechos humanos en nuestro sistema jurisdiccional.

Palabras clave: Derechos humanos. Educación. Formación de Magistrados.

\section{INTRODUÇÃO.}

Durante o "IV Congresso Internacional de Direitos Humanos de Coimbra: uma visão transdisciplinar", em 2019, no desenrolar do "Simpósio

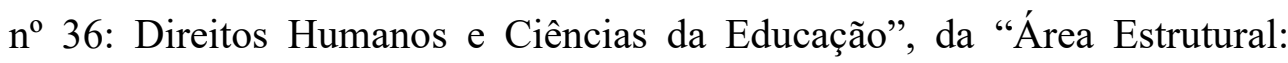
Filosofia, Formação de Professores e de Pesquisadores em Direitos Humanos", coordenada por César Aparecido Nunes e Antonio Gomes Ferreira, apresentei o resumo de um projeto de pesquisa sobre "A (In)Eficácia da Formação dos Magistrados Brasileiros em Direitos Humanos e Controle de Convencionalidade".

Esse projeto de pesquisa foi elaborado e desenvolvido com a preocupação de verificar a eficácia da formação de magistradas e magistrados brasileiros no campo epistemológico, ético e político do sistema de proteção dos direitos humanos no âmbito de uma cultura jurídica conservadora e tradicional, posto que hegemônica, que resiste ao avanço e à consolidação do ethos de uma nova cultura jurídica e política embasada na dignidade humana, como ensina Cesar Augusto (2019). E essa preocupação é justificável, ainda hoje, porque, no Brasil, superado o período da ditadura civil militar que se abateu sobre a sociabilidade brasileira a partir de 1964, a

Filos. e Educ., Campinas, SP, v.12, n.2, p.1085-1125, maio/ago. 2020 - ISSN 1984-9605 
Constituição Federal de 1988, empolgada por novos paradigmas democráticos, rompendo com uma cultura excludente, autoritária e impositiva, elegeu a dignidade humana e a preeminência dos direitos humanos como princípios fundamentais ${ }^{2}$ e incumbiu aos juízes e juízas a realização da tarefa de garantir esses direitos, de forma plena e efetiva, no âmbito judicial da superestrutura e da subjetividade do poder.

Como um construído axiológico, a partir de um espaço simbólico de luta e de ação social, as convenções e os tratados internacionais de direitos humanos ratificados pelo Brasil passaram a integrar, desde então, sob o arnês de uma nova ordem política e jurídica, de modo indivisível, obrigatório e vinculante, o bloco de constitucionalidade do sistema jurídiconormativo brasileiro. E, como já afirmou o Supremo Tribunal Federal, em 2009, ao proferir paradigmática decisão, além de conferir às normas dos tratados e convenções internacionais de direitos humanos força inibitória da eficácia das normas internas com eles conflitantes $^{3}$, asseverou que a Constituição Federal confiou ao Poder Judiciário a "alta missão" de concretizar os direitos humanos como uma das mais expressivas funções políticas da atividade jurisdicional. ${ }^{4}$ Mas, não é só. A Corte Interamericana de Direitos Humanos também afirmou, na decisão proferida no Caso Arillano e outros vs Chile, que juízas e juízes internos devem realizar o "controle de convencionalidade", ou seja, devem garantir a prevalências dos paradigmas e princípios éticos e jurídicos dos direitos humanos, nos casos concretos em que atuam, considerando, inclusive, a interpretação da Corte Interamericana de Direitos Humanos, cuidando, assim, de assegurar a preeminência do sistema de proteção dos direitos humanos.

Portanto, aos magistrados brasileiros compete aplicar as regras e princípios normativos de direitos humanos e realizar o controle difuso da convencionalidade das leis, declarando-as inválidas diante de eventual antinomia com o sistema de proteção dos direitos humanos. É por isso que a ENFAM - Escola Nacional de Formação e Aperfeiçoamento de Magistrados

${ }^{2} \mathrm{CF} / 88$, art. $1^{\circ}$, III e art. $4^{\circ}$, II
${ }^{3} \mathrm{RE} 466.343$

${ }^{3}$ RE 466.343
ADPF 54

Filos. e Educ., Campinas, SP, v.12, n.2, p.1085-1125, maio/ago. 2020 - ISSN 1984-9605 
Ministro Sálvio de Figueiredo Teixeira, cumprindo a sua função constitucional, nos termos do artigo 105 , $\S$ único, inciso I da $\mathrm{CF} / 88$, ao regulamentar os cursos de formação das escolas judiciais e de magistratura sob sua égide, adotou a temática dos direitos humanos como obrigatória, incluindo o "controle de convencionalidade" no conteúdo programático de disciplina específica e cursos especiais. ${ }^{5}$

Aliás, como já observou Cesar Nunes (2019), a escola, na sua dimensão genérica, é uma instituição basilar da sociedade, nasce da prática social e reflete as contradições da sociedade de classes, mas, a sua função política é contraditória e "pode ser alinhada para conservar e para reproduzir as práticas sociais dominantes, quanto pode, contraditoriamente, superar e transformar as práticas sociais usuais, abrindo espaços para novas hegemonias a serem amiúde conquistadas pela luta política e pela materialidade cultural". 6

Assim, ao adotar a temática predominante dos Direitos Humanos como valor primacial e transversal da formação dos magistrados e magistradas, e empolgada pela principiologia constitucional embasada na ética e no humanismo, bem como pelos paradigmas do Plano Nacional de Educação em Direitos Humanos, a ENFAM assumiu uma postura orgânica, no sentido gramsciano, para superar e transformar as práticas sociais usuais, bem como a cultura jurídica tradicional e conservadora, "abrindo espaços

\footnotetext{
${ }^{5}$ RESOLUÇÃO/ENFAM N.2, de 8 de junho de 2016. Dispõe sobre os programas para a formação e 0 aperfeiçoamento de magistrados e regulamenta os cursos oficiais para o ingresso, a formação inicial e o aperfeiçoamento de magistrados e de formadores. CURSO DE FORMAÇÃO INICIAL. ANEXO I. CONTEÚDO PROGRAMÁTICO MÍNIMO PARA O CURSO DE INGRESSO. NA CARREIRA DA MAGISTRATURA. Tema $V$ - DIREITOS HUMANOS. Teoria dos Direitos Fundamentais. Direitos humanos: história, fontes e formação dos direitos humanos. Panorama histórico. Tratados internacionais e função dos organismos internacionais. Investigação de violações (nacional e internacional). Direito internacional dos direitos humanos e as ordens jurídicas nacionais. Controle da convencionalidade. A internacionalização dos tratados. Jurisdição universal. Casos de repercussão no Brasil. Soberania e imunidades. Indicadores de direitos humanos. Segurança nacional, conflito armado, terrorismo e direitos.

${ }^{6}$ Cesar Nunes, Direitos Humanos. Educação e4 Democracia, Capítulo 2, Educação em Direitos Humanos no Brasil Atual: fundamentos políticos e práticas pedagógicas emancipatórias possíveis, Ed. Brasílica, Campinas/SP, 2019, p. 35
}

Filos. e Educ., Campinas, SP, v.12, n.2, p.1085-1125, maio/ago. 2020 - ISSN 1984-9605 
para novas hegemonias a serem conquistadas pela luta política e pela materialidade cultural".

Nesse sentido, a partir de 2016, todos os juízes e juízas que ingressaram na magistratura nacional, por concurso público, no âmbito estadual ou federal, participaram de cursos sobre Direitos Humanos, ministrados pela ENFAM e pelas escolas locais ou regionais de formação de magistrados, sobretudo com a abordagem do "controle de convencionalidade", visando ao aperfeiçoamento da atividade jurisdicional com embasamento em princípios éticos e humanistas, de acordo com os projetos e planos de cursos elaborados e aprovados com o objetivo de garantir a concretização da dignidade dos jurisdicionados e o império dos direitos humanos.

Ademais, o Plano Nacional de Educação em Direitos Humanos, elaborado pelo Comitê Nacional de Educação em Direitos Humanos, da Secretaria Especial dos Direitos Humanos da Presidência da República e dos Ministérios da Educação e da Justiça, sob a orientação da UNESCO, afirma, especialmente com relação à "Educação dos Profissionais dos Sistemas de Justiça e Segurança”, que "os direitos humanos são condições indispensáveis para a implementação da justiça e da segurança pública em uma sociedade democrática", que "a capacitação de profissionais dos sistemas de justiça e segurança é, portanto, estratégica para a consolidação da democracia", que "a educação em direitos humanos constitui um instrumento estratégico no interior das políticas de segurança e justiça para respaldar a consonância entre uma cultura de promoção e defesa dos direitos humanos e os princípios democráticos" e, ainda, que "o ensino dos direitos humanos deve ser operacionalizado nas práticas desses(as) profissionais, que se manifestam nas mensagens, atitudes e valores presentes na cultura das escolas e academias, nas instituições de segurança e justiça e nas relações sociais”, o que está a exigir, como uma de suas ações programáticas, a criação e a promoção de "programas básicos $e$ conteúdos curriculares obrigatórios, disciplinas e atividades complementares em direitos humanos, nos programas para formação e 
educação continuada dos profissionais de cada sistema (segurança $e$ justiça), considerando os princípios da transdisciplinaridade e da interdisciplinaridade".

É preciso, pois, verificar se a formação dos juízes e juízas em direitos humanos tem sido eficaz. Aliás, é imprescindível verificar, também, se há carência dessa formação continuada para os juízes e juízas que ingressaram na carreira da magistratura ao longo dos últimos anos e, especialmente, antes da implantação dos cursos sobre direitos humanos nas escolas judiciais ou de magistratura. E esse foi o objetivo estabelecido pela pesquisa ora em comento: verificar se os magistrados e magistradas estão aplicando as normas de direitos humanos e realizando o controle de convencionalidade, ou seja, se estão garantindo, em sua atividade jurisdicional, a prevalência das normas, regras e princípios germinais do sistema de proteção dos direitos humanos e, consequentemente, analisar se há necessidade da implantação ou ampliação de cursos sobre direitos humanos, sobretudo com aprofundamento do "controle de convencionalidade", para juízes e juízas e, ainda, se têm sido eficazes os cursos de formação em direitos humanos e controle de convencionalidade ministrados pela ENFAM e, também, pelas Escolas judiciais e de magistratura, estaduais e federais, sobretudo no processo pedagógico de sua formação inicial.

A metodologia qualitativa orientou a pesquisa, que ainda está em fase de desenvolvimento, na modalidade de Estudo de Casos, com enfoque crítico-hermenêutico. Para garantir a necessária abrangência e diversidade à pesquisa, festão sendo analisadas decisões proferidas, a partir de 2015, por mais de 50 juízes e juízas, na Comarca de Campinas, que tem mais de 1.000.000 de habitantes e conta com 38 unidades (varas) judiciais, várias delas especializadas e com grande diversidade de competências, tanto na área cível como no âmbito criminal. Depois, na continuidade da pesquisa, será examinado o histórico da formação dos prolatores das decisões analisadas para verificar se realizaram cursos sobre Direitos Humanos e sobre Controle de Convencionalidade, aferindo-se, assim, a eficácia de 
eventual formação ou a pressuposta consequência de sua ausência, na perspectiva de uma interpretação histórico-crítica e jurídica de conjunto e de totalidade.

$\mathrm{Na}$ hipótese estabelecida, as escolas judiciais e de magistratura devem aprofundar e expandir a formação dos magistrados com relação à aplicação dos direitos humanos, pois a deficiência da formação, nesse particular, acarreta prejuízo à concretização dos direitos humanos, especialmente, das pessoas mais vulneráveis, reforçando as desigualdades sociais. Aliás, recentemente, o Papa Francisco, em reunião com juízes e juízas de vários países, chamando-os de "poetas sociais", afirmou que "a cada falha no palco dos direitos econômicos, sociais e culturais, o juiz produz desigualdade e incrementa as dinâmicas de exclusão e segregação". Portanto, cabe às escolas judiciais e de magistratura a função orgânica de promover a formação dos juízes e juízas para a efetivação dos direitos humanos e garantia da dignidade humana.

Todavia, em 2006, uma pesquisa realizada pela CEMICAMP $^{7}$ revelou que apenas $2,7 \%$ dos magistrados brasileiros haviam lido a Convenção Americana de Direitos Humanos (Pacto de San Jose da Costa Rica) e, ainda, que $46,8 \%$ jamais haviam lido qualquer tratado ou convenção sobre direitos humanos. ${ }^{8} \mathrm{E}$ outra pesquisa, recentemente

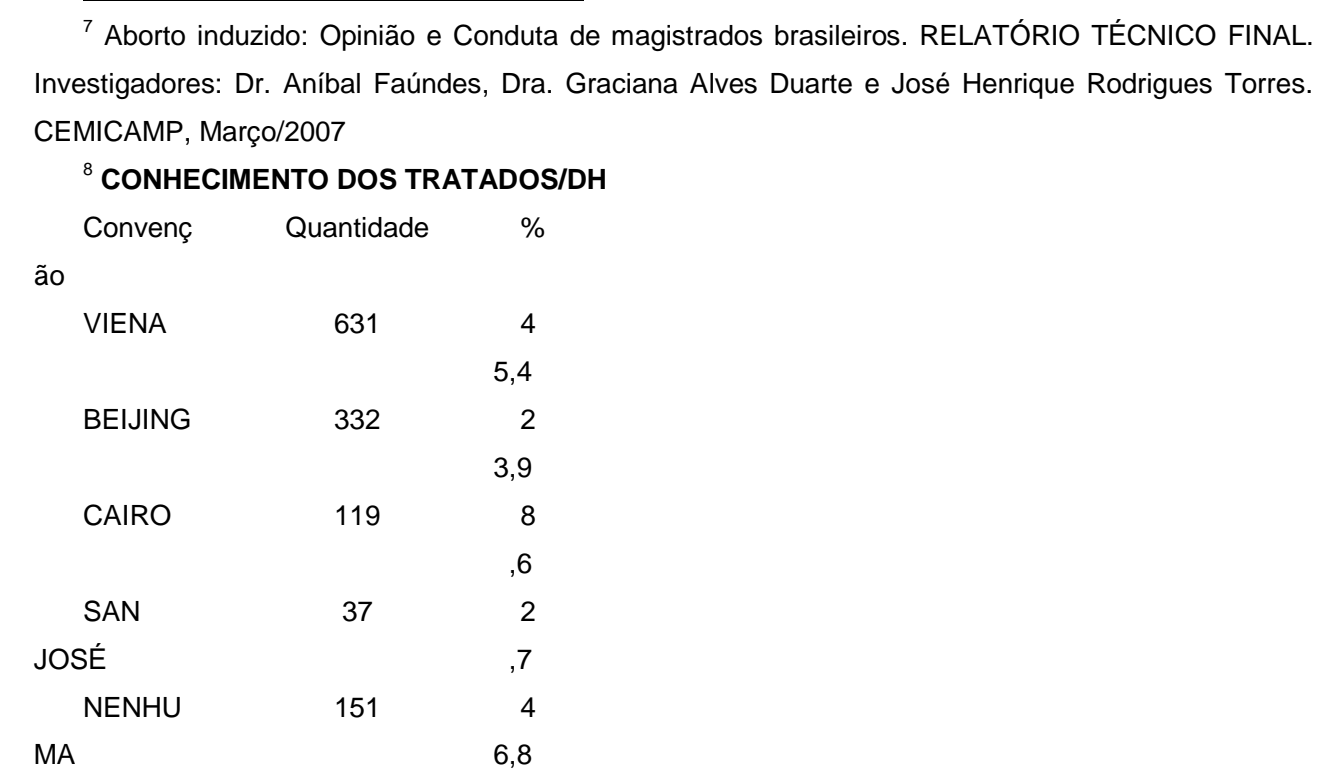

Filos. e Educ., Campinas, SP, v.12, n.2, p.1085-1125, maio/ago. 2020 - ISSN 1984-9605 
realizada também em Campinas, revelou o seguinte: em 2018, foram proferidas 35.236 sentenças pelos juízes e juízas das várias unidades (varas) judiciais da comarca de Campinas; em apenas 30 dessas sentenças houve menção à expressão "direitos humanos"; e de nenhuma delas consta a expressão "controle de convencionalidade". 9

\section{DA CONSTITUCIONALIDADE DOS DIREITOS HUMANOS E DO DEVER DOS MAGISTRADOS E MAGISTRADAS DE GARANTIR A SUA EFETIVIDADE.}

De acordo com a interpretação sistemática e teleológica do texto constitucional, e considerando a força expansiva dos valores da dignidade humana e dos direitos fundamentais como parâmetros axiológicos, todas as normas de direitos humanos são materialmente constitucionais ${ }^{10}$. Com efeito, nos termos do artigo $5^{\circ}$, parágrafos $2^{\circ}$ e $3^{\circ}$ de sua Constituição Federal, o Brasil incorporou o sistema de proteção dos direitos humanos em sua ordem normativa interna e em seu sistema jurídico-constitucional. Mas, além de constitucionais, todas as normas de direitos humanos emergentes dos Tratados e Convenções internacionais ratificados pelo Brasil estão metidas a rol entre as garantias fundamentais, com natureza de cláusula pétrea, nos termos do artigo $60, \S 4^{\circ}$, IV da $\mathrm{CF} / 88$.

Como assevera Flávia Piovesan, invocando ensinamentos de Antônio Augusto Cançado Trindade e de José Joaquim Gomes Canotilho, "os direitos garantidos nos tratados de Direitos Humanos de que o Brasil é parte, integram o elenco dos direitos constitucionalmente consagrados.

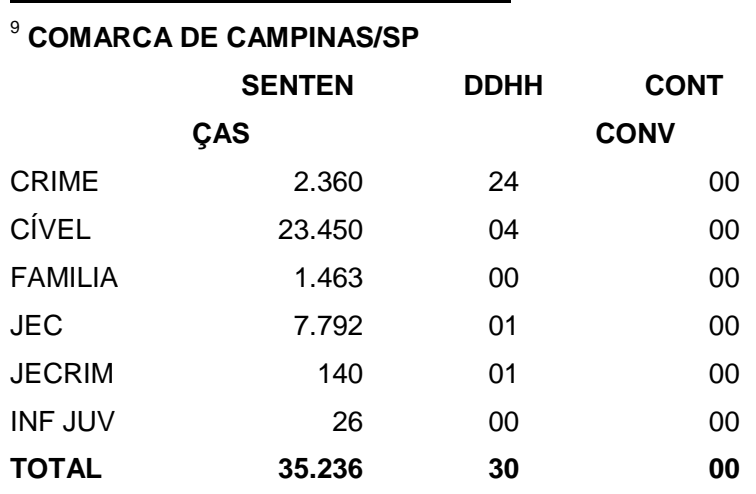

\footnotetext{
${ }^{10} \mathrm{CF}$, art. $5^{\circ}$, $\S 2^{\circ}$. Os tratados aprovados com quórum especial, nos termos do $\S 3^{\circ}$, são também formalmente constitucionais.
}

Filos. e Educ., Campinas, SP, v.12, n.2, p.1085-1125, maio/ago. 2020 - ISSN 1984-9605 
Essa conclusão advém, ainda, da interpretação sistemática e teleológica do texto, especialmente em face da força expansiva dos valores da dignidade humana e dos direitos fundamentais, com parâmetros axiológicos a orientar a compreensão do fenômeno constitucional". ${ }^{11}$ E, como ensina Ingo Wolfgang Sarlet na obra Comentários à Constituição do Brasil, organizada pelo nomeado constitucionalista e, também, por J.J. Gomes Canotillho, Gilmar Ferreira Mendes e Lênio Streck, "a norma contida no $\S 2^{\circ}$ do art. $5^{\circ}$ da CF traduz o entendimento de que, além dos direitos expressamente positivados no capítulo constitucional próprio (dos direitos e garantias fundamentais), existem direitos que, por seu conteúdo e significado, integram o sistema da Constituição, compondo, em outras palavras, na acepção originária do direito constitucional francês, o assim chamado bloco de constitucionalidade, que não se restringe necessariamente a um determinado texto ou mesmo conjunto de textos constitucionais, ou seja, não se reduz a uma concepção puramente formal de constituição e de direitos fundamentais. Assim, a despeito do caráter analítico do Título II da $C F$, onde estão contidos os direitos e garantias como tal designados $e$ reconhecidos pelo constituinte, cuida-se de uma numeração não taxativa. $O$ art. $5^{\circ}, \S 2^{\circ}$ da CF representa, portanto, uma cláusula que consagra a abertura material do sistema constitucional de direitos fundamentais como sendo um sistema inclusivo e amigo dos direitos fundamentais". ${ }^{2}$

Assim, “interpretando-se o $\S 3^{\circ}$ do art. $5^{\circ}$ da CF no contexto onde se inserem os tratados de direitos humanos na Constituição, chega-se à conclusão de que os tratados de direitos humanos ratificados pelo Brasil já têm status de norma constitucional em virtude do disposto no $\S 2^{\circ}$ do art. $5^{\circ}$ da Constituição, segundo o qual os direitos e garantias expressos no texto constitucional 'não excluem outros decorrentes do regime e dos princípios por ela adotados, ou dos tratados internacionais em que a República Federativa do Brasil seja parte', pois na medida e que a Constituição não exclui os direitos humanos provenientes de tratados, é porque ela própria os inclui nos seu catálogo de direitos protegidos, ampliando o seu 'bloco de

\footnotetext{
${ }^{11}$ Direitos humanos e o direito constitucional internacional, pg. 83, Ed. Max Limonad, SP, 1996

${ }^{12}$ Comentários à Constituição do Brasil, Editora Saraiva, Almedina e IDD, São Paulo, 2013, p. 517.
} 
constitucionalidade' e atribuindo-lhes hierarquia de norma constitucional". 13

Como se vê, o sistema internacional de proteção dos Direitos Humanos foi incorporado ao sistema jurídico brasileiro com natureza constitucional e seus dispositivos garantistas estão marcados com o sinete indelével das cláusulas pétreas, o que as torna irrevogáveis e imutáveis. Aliás, segundo esclarece o Conselho Nacional de Justiça, "o termo cláusula pétrea traduz a vontade da Assembleia Constituinte de retirar do poder constituinte reformador - parlamentares que compõem as sucessivas legislaturas - a possibilidade de alterar determinado conteúdo da Constituição em razão de sua importância. Assim, para alterar o conteúdo de uma dessas cláusulas de pedra, somente a promulgação de uma nova constituição. As chamadas cláusulas pétreas estão enumeradas no artigo 60, $\S 4^{\circ}$ da Carta Magna. Além do voto, um direito político que é especificado no artigo 14, também são considerados como cláusulas pétreas da Constituição os direitos e garantias individuais, a forma federativa do Estado brasileiro e a separação dos poderes. São consideradas o "núcleo duro do texto constitucional, indispensáveis à cidadania e ao Estado brasileiro. E os direitos e garantias individuais estão enunciados ao longo do texto constitucional, em especial no artigo $5^{\circ}$. Também se classificam como tais os direitos sociais, que, de acordo com o artigo $6^{\circ}$ da Constituição, são a educação, a saúde, a alimentação, o trabalho, a moradia, o transporte, o lazer, a segurança, a previdência social, a proteção à maternidade e à infância e a assistência aos desamparados, conforme descritos na Carta Magna. Novos direitos e garantias ainda podem ser acrescentados à Constituição". Portanto, os direitos humanos, metidos a rol entre os direitos e garantias individuais, por força do disposto no $\S 2^{\circ}$ do artigo $5^{\circ}$ da $\mathrm{CF} / 88$, são normas constitucionais e cláusulas pétreas.

Em consequência, obviamente, é imprescindível que juízas e juízes brasileiros estejam preparados para realizar a tarefa constitucional de

\footnotetext{
${ }^{13}$ Ingo Wolfgang Sarlet. op. cit. p. 520.
} 
garantir a aplicação e prevalência do sistema de proteção dos direitos humanos, sobretudo em homenagem à dignidade das pessoas e à ética democrática, realizando a aplicação de suas normas, regras e princípios, e, ainda, realizando o "controle de convencionalidade".

No dizer de Mazzuoli (2009), “a Emenda Constitucional n. 45/2004, que acrescentou o $\S 3^{\circ}$ ao artigo $5^{\circ}$ da $\mathrm{CF}$, trouxe a possibilidade de os tratados internacionais de direitos humanos serem aprovados com um quórum qualificado a fim de passarem (...) de um status materialmente constitucional para a condição (formal) de tratados equivalentes às 'emendas constitucionais. Tal acréscimo constitucional trouxe ao direito brasileiro um novo tipo de controle à produção normativa doméstica, até hoje desconhecida entre nós, o controle de convencionalidade das leis. Assim, à medida que os tratados de direitos humanos ou são materialmente constitucionais (artigo $5^{\circ}, \S 2^{\circ}$ ) ou material e formalmente constitucional (artigo $5^{\circ}, \S 3^{\circ}$ ), é lícito entender que, para além do clássico controle de constitucionalidade, deve ainda existir um controle de convencionalidade das leis, que é a compatibilização da produção normativa doméstica com os tratados de direitos humanos ratificados pelo governo e em vigor no país". ${ }^{4}$

Com efeito, como ensina Cançado Trindade, "os órgãos do Poder Judiciário de cada Estado Parte da Convenção Americana devem conhecer a fundo e aplicar devidamente, não apenas o Direito Constitucional, mas, também, o Direito Internacional dos Direitos Humanos; devem exercer, de ofício, o controle tanto de constitucionalidade como de convencionalidade, tomados em conjunto, pois os ordenamentos jurídicos internacional e nacional encontram-se em constante interação no contexto de proteção da pessoa humana". E a Corte Interamericana de Direitos Humanos afirmou, recentemente, no julgamento do Caso Arellano e outros Vs Chile, que, quando um Estado ratifica um tratado internacional, como a Convenção, seus juízes, como parte do aparato do Estado, também estão submetidos a ela, o que os obriga a velar para que os efeitos das disposições da

\footnotetext{
${ }^{14}$ Valério de Oliveira Mazzuoli O controle jurisdicional da convencionalidade, RT, São Paulo, 2009, p.75
} 
Convenção não se vejam prejudicados pela aplicação de leis contrárias ao seu objeto e fim, e que, desde o seu início, carecem de efeitos jurídicos. Em outras palavras, o Poder judiciário deve exercer uma espécie de controle de convencionalidade entre as normas jurídicas internas que aplicam nos casos concretos e a Convenção Americana sobre Direitos Humanos. Nessa tarefa, o Poder Judiciário deve ter em conta não somente o tratado, senão também a interpretação que dele tem feito a Corte Interamericana, intérprete última da Convenção Americana. ${ }^{15}$ Como se vê, essa decisão da Corte Interamericana de Direitos Humanos deixou absolutamente claro que, além do dever de verificação da compatibilidade das normas com o sistema constitucional, constitui dever das juízas e juízes internos, controlar, também, a convencionalidade das leis em face do disposto nos tratados de direitos humanos em vigor no país, observando suas normas positivadas, seus princípios e, ainda, a sua interpretação pro homine ou pro persona.

O controle de compatibilidade das leis com o sistema internacional de proteção dos direitos humanos, portanto, não é mera faculdade conferida aos magistrados nacionais, mas, sim, uma irrenunciável incumbência. Em sua atividade jurisdicional, os juízes e juízas devem, sempre e sempre, verificar se as normas internas guardam ou não compatibilidade com as normas e princípios do sistema internacional de proteção dos Direitos Humanos e, especialmente, com os dispositivos normativos e princípios da Convenção Americana de Direitos Humanos (Pacto de San José da Costa Rica). Cabe aos juízes e juízas, em suas decisões, afastar a aplicação de normas jurídicas de caráter legal que contrariem tratados internacionais que versam sobre Direitos Humanos, como a Convenção Americana de Direitos Humanos de 1969 (Pacto de São José da Costa Rica), o Pacto Internacional sobre Direitos Civis e Políticos de 1966 e o Pacto Internacional dos Direitos Econômicos, Sociais e Culturais de 1966 (PIDESC), bem como as orientações expedidas pelos denominados treaty bodies, a Comissão Interamericana de Direitos Humanos e o Conselho de Direitos Humanos das Nações Unidas, e, ainda, a jurisprudência das instâncias judiciárias p. 73

${ }^{15}$ Valério de Oliveira Mazzuoli, Controle Jurisdicional de Convencionalidade, RT, São Paulo: 2009,

Filos. e Educ., Campinas, SP, v.12, n.2, p.1085-1125, maio/ago. 2020 - ISSN 1984-9605 
internacionais de âmbito americano e global, a Corte Interamericana de Direitos Humanos e o Tribunal Internacional de Justiça da Organização das Nações Unidas, respectivamente.

Enfim, como assevera Dalmo de Abreu Dallari, "nas sociedades democráticas modernas, submetidas ao império do direito, a proteção dos direitos humanos é tarefa que incumbe ao Poder Judiciário". ${ }^{16}$

Decididamente, nas palavras do Ministro Celso de Mello, do STF, "o Poder Judiciário constitui o instrumento concretizador das liberdades civis, das franquias constitucionais e dos direitos fundamentais assegurados pelos tratados e convenções internacionais subscritos pelo Brasil. Essa alta missão, que foi confiada aos juízes e Tribunais, qualifica-se como uma das mais expressivas funções políticas do Poder Judiciário". ${ }^{17}$

\section{A APLICAÇÃO DAS NORMAS DE DIREITOS HUMANOS E A REALIZAÇÃO DO CONTROLE DE CONVENCIONALIDADE NAS DECISÕES JUDICIAIS}

Em 2006, como acima já deixei consignado, uma pesquisa realizada pela CEMICAMP, revelou um imenso desconhecimento dos juízes e juízas, estaduais e federais, de todas as instâncias de julgamento, sobre o sistema de proteção de direitos humanos e, consequentemente, sobre a necessidade e obrigatoriedade de sua aplicação no exercício de sua atividade jurisdicional.

Segundo o resultado da mencionada pesquisa, apenas $2,7 \%$ de magistradas e magistrados brasileiros haviam lido, por exemplo, a Convenção Americana de Direitos Humanos, também conhecida como Pacto de San Jose da Costa Rica. E não se olvide que essa convenção foi ratificada pelo Brasil em 1992 (assinada na Conferência Especializada Interamericana sobre Direitos Humanos, San José, Costa Rica, em 22 de novembro de 1969; promulgada, no Brasil, pelo Decreto n. 678, de 06 de novembro de 1992). Assim, apesar de quase quinze anos de vigência desse tratado internacional de direitos humanos, que é a principal norma do sistema interamericano de proteção e garantia dos direitos humanos, os seus

\footnotetext{
16 O poder dos juízes, Saraiva, SP, 1996

17 STF - 12/04/2012 - PLENÁRIO, ADPF - Arguição de Descumprimento de Preceito Fundamental n. 54
}

Filos. e Educ., Campinas, SP, v.12, n.2, p.1085-1125, maio/ago. 2020 - ISSN 1984-9605 
dispositivos, que têm status constitucional e constituem garantias individuais, marcadas com a cláusula da irrevogabilidade inclusive, eram ignorados por quase a totalidade dos juízes e juízas do Brasil, os quais, por imposição constitucional, deveriam ser os "guardiães" do sistema constitucional e do sistema de proteção dos direitos humanos.

E não se pode olvidar que, nos termos dessa convenção, incorporada ao nosso sistema constitucional como garantia individual e cláusula pétrea, o Brasil, como os demais Estados signatários, comprometeram-se a "respeitar os direitos e liberdades nela reconhecidos e a garantir seu livre e pleno exercício a toda pessoa que está sujeita à sua jurisdição, sem qualquer discriminação". Além disso, segundo expressam os dispositivos dessa norma convencional, se o exercício de tais direitos e liberdades ainda não estiver assegurado na legislação interna, os Estados membros estão obrigados a adotar as medidas legais ou de outro caráter para que estes direitos venham a tornar-se efetivos. Portanto, diante da importância jurídica e normativa desse tratado internacional, é inadmissível que mais de $90 \%$ dos juízes e juízas nem sequer o tenham lido e, consequentemente, não o tenham aplicado e respeitado em sua atividade jurisdicional durante tantos anos.

Mas não é só. Segundo outro resultado da pesquisa em menção, 46,8\% dos juízes e juízas jamais haviam lido qualquer tratado ou convenção internacional sobre direitos humanos, o que representava, naquele momento, um imenso desafio para as escolas judiciais e de magistratura brasileiras em face de um abissal desconhecimento sobre o sistema de proteção dos direitos humanos exatamente por aqueles encarregados de sua garantia, aplicação e prevalência.

Entretanto, depois dessa pesquisa, que desvelou, em 2006, como acima já deixei consignado, que juízas e juízes brasileiros tinham pouco conhecimento sobre o sistema de proteção dos direitos humanos, o que, obviamente, aniquilava quase que totalmente a possibilidade de sua aplicação na atividade jurisdicional, houve muitos avanços e conquistas no campo educacional, no que diz respeito à implantação curricular, específica ou transversal, dessa temática dos direitos humanos e de seu conteúdo 
pedagógico na esfera universitária, sobretudo nas faculdades de direito e, inclusive, nos cursos preparatórios para as carreiras jurídicas, o que deveria ter acarretado um movimento de transformação na cultura jurídica tradicional prevalente e resistente na magistratura nacional.

Aliás, por sugestão da AJD - Associação Juízes para a Democracia, Paulo Vannuchi, que exerceu o cargo de Ministro de Estado Chefe da Secretaria Especial de Direitos Humanos da Presidência da República até 2010, apresentou à Presidência da OAB - Ordem dos Advogados do Brasil, uma proposta de introdução da disciplina "Direitos Humanos" no Exame de Ordem, proposta essa que, forte nas reivindicações de movimentos sociais e, também, no âmbito da advocacia nacional, foi acolhida e implantada, a partir de 2011, o que provocou e possibilitou a ampliação do estudo dos direitos humanos, acarretando, axiomaticamente, para todos os cursos preparatórios para o Exame de Ordem, a obrigação de promoverem o seu estudo.

Além disso, as Faculdades de Direito, que estavam implantando o estudo e a pesquisa sobre direitos humanos de forma bastante tímida, salvo algumas exceções pioneiras e pontuais, como ocorreu com a Faculdade de Direito da Pontifícia Universidade Católica de São Paulo, também ampliaram, gradualmente, os currículos de seus cursos para introduzir a disciplina Direitos Humanos, criando, inclusive, novos cursos de pós graduação em Direitos Humanos, com maior intensidade e abrangência.

E a ENFAM, como acima já adiantei, em 2016, compreendendo que aos magistrados e magistradas compete aplicar as normas, regras e princípios de direitos humanos e realizar o controle difuso da convencionalidade das leis, adotou a disciplina de direitos humanos como obrigatória para todos os cursos de formação inicial dos magistrados e magistradas estaduais e federais, incluindo o "controle de convencionalidade" no seu conteúdo programático $^{18}$. A partir de 2016,

\footnotetext{
${ }^{18}$ RESOLUÇÃO/ENFAM N.2, de 8 de junho de 2016. Dispõe sobre os programas para a formação e o aperfeiçoamento de magistrados e regulamenta os cursos oficiais para 0 ingresso, a formação inicial e o aperfeiçoamento de magistrados e de formadores. CURSO DE FORMAÇÃO INICIAL.
} 
portanto, todos os juízes e juízas estaduais e federais aprovados em concursos públicos participaram de cursos de formação inicial realizando aulas de Direitos Humanos e Controle de Convencionalidade.

Todavia, a fase inicial da pesquisa que está sendo realizada em Campinas, objeto desta análise, posto que ainda não concluída, já é bastante para revelar que o sistema normativo de proteção dos Direitos Humanos ainda não foi incorporado pelos magistrados e magistradas e não tem sido aplicado nas decisões proferidas pelo sistema de justiça. Com efeito, segundo desvelado por essa pesquisa, em 2018, por exemplo, foram proferidas 35.236 sentenças pelos juízes e juízas de 33 unidades (varas) judiciais da Comarca de Campinas, mas, em apenas 30 dessas sentenças houve menção à expressão "direitos humanos" e de nenhuma delas consta ter sido utilizada a expressão "controle de convencionalidade.

Essa pesquisa foi realizada na Comarca de Campinas/SP, que tem 1.200.000 habitantes, 838.532 eleitores e um total de 54 juízes e juízas, trabalhando em 38 varas judiciais.

ANEXO I. CONTEÚDO PROGRAMÁTICO MÍNIMO PARA O CURSO DE INGRESSO. NA CARREIRA DA MAGISTRATURA. Tema $V$ - DIREITOS HUMANOS. Teoria dos Direitos Fundamentais. Direitos humanos: história, fontes e formação dos direitos humanos. Panorama histórico. Tratados internacionais e função dos organismos internacionais. Investigação de violações (nacional e internacional). Direito internacional dos direitos humanos e as ordens jurídicas nacionais. Controle da convencionalidade. A internacionalização dos tratados. Jurisdição universal. Casos de repercussão no Brasil. Soberania e imunidades. Indicadores de direitos humanos. Segurança nacional, conflito armado, terrorismo e direitos.

Filos. e Educ., Campinas, SP, v.12, n.2, p.1085-1125, maio/ago. 2020 - ISSN 1984-9605 


\begin{tabular}{|c|c|c|c|}
\hline \multicolumn{3}{|c|}{ SENTENÇAS PROFERIDAS EM 2018} \\
\hline Varas Criminais & 2.360 & DDHH $=24$ & $(0,15 \%)$ \\
\hline Varas Cíveis & 23.450 & DDHH $=04$ & $(0,11 \%)$ \\
\hline Varas de Família & 1.463 & DDHH $=00$ & \\
\hline Varas & 7.832 & DDHH $=02$ & $(0,07 \%)$ \\
\hline JEC/JECRIM & 26 & DDHH $=00$ & \\
\hline Varas de INF JUV & & DDHH = & $(\mathbf{0 , 0 8 \% )}$ \\
\hline TOTAL & $\mathbf{3 5 . 2 3 6}$ & $\mathbf{3 0}$ & \\
\hline
\end{tabular}

Foram verificadas, pelo sistema de consulta do SAJ, todas as sentenças proferidas em 33 das 38 varas judiciais da Comarca de Campinas (06 varas criminais centrais, 10 varas cíveis centrais, 01 vara do Juizado Especial Criminal, 05 Varas do Foro Regional da Vila Mimosa, 05 Varas do Juizado Especial Cível, 04 Varas de Família e Sucessões e 02 varas do Júri). De 2015 a 2019, foram proferidas 186.725 sentenças, mas, em apenas 207

SENTENÇAS PROFERIDAS NA COMARCA DE CAMPINAS (2015 a 2019)

\begin{tabular}{|c|c|c|c|}
\hline 2015 & 34.680 & DDHH = 54 & $(0,15 \%)$ \\
\hline 2016 & 36.489 & DDHH = 42 & $(0,11 \%)$ \\
\hline 2017 & 41.438 & DDHH = 34 & $(0,08 \%)$ \\
\hline 2018 & 35.236 & DDHH $=30$ & $(0,08 \%)$ \\
\hline 2019 & 38.882 & DDHH $=47$ & $(0,12 \%)$ \\
\hline TOTAL/SENTENÇAS & $\mathbf{1 8 6 . 7 2 5}$ & DH $=\mathbf{2 0 7}$ & $\mathbf{( 0 , 1 1 \% )}$ \\
\hline
\end{tabular}

$(\mathrm{O}, 11 \%)$ havia a expressão "direitos humanos". 
É verdade que ainda há necessidade do estudo do teor das sentenças que utilizaram a expressão "direitos humanos" e, também, daquelas que fizeram referência ao "Controle de Convencionalidade", para identificar os temas que foram abordados e as questões enfrentadas sob a égide das normas e princípios do sistema de proteção dos direitos humanos, o que poderá permitir a análise das decisões que envolvem a mesma questão sem a aplicação dos dispositivos ou paradigmas convencionais.

E também é imprescindível que seja analisada a formação dos juízes e juízas que prolataram essas decisões, para verificar se participaram de cursos de direitos humanos ministrados pelas escolas judiciais ou de magistratura.

Entretanto, os mencionados dados, obtidos nessa primeira fase da pesquisa, já são suficientes para evidenciar a ínfima e incipiente utilização do sistema normativo de direitos humanos para o embasamento das sentenças, bem como a diminuta quantidade de enfrentamento teórico das questões relativas aos direitos humanos, as quais não foram sequer enfrentadas na quase totalidade das decisões.

4. EM TEMPOS DE PANDEMIA, A PRISÃO PREVENTIVA E OMISSÃO DAS DECISÕES QUANTO AOS PARADIGMAS DOS DIREITOS HUMANOS.

Outra pesquisa realizada em Campinas, em 2020, abordando "a formação dos juízes e juízas para a proteção dos direitos humanos, a pandemia da Covid 19 e as prisões preventivas", na esteira da pesquisa em análise, também evidencia a necessidade da ampliação da formação dos juízes e juízas para o exercício de sua tarefa constitucional de aplicação e garantia da prevalência dos direitos humanos em nosso ordenamento jurídico-constitucional.

Nessa pesquisa, que também está em fase de desenvolvimento e que será apresentada, neste ano, durante o V Congresso Internacional de Direitos Humanos de Coimbra, no Simpósio n ${ }^{\circ}$ 14: Direitos Humanos, Ciências da Educação e as Abordagens Metodológicas Atuais, coordenado 
por Cesar Aparecido Nunes e Antonio Gomes Ferreira, estão sendo analisadas decisões judiciais proferidas no momento emergencial da pandemia da Covid-19, ${ }^{19}$ abordando o cabimento, a decretação ou a mantença de prisões preventivas, com o objetivo de verificar se as normas e recomendações do sistema internacional de proteção dos direitos humanos estão sendo consideradas em sua fundamentação.

O sistema normativo e principiológico de proteção dos direitos humanos (v. g. DADDH, ${ }^{20} \mathrm{CADH}^{21} \mathrm{PSS}^{22}$ e $\mathrm{CSA}^{23}$ ) garante, genericamente, a todas as pessoas, o direito ao mais alto nível de assistência à saúde. ${ }^{24} \mathrm{E}$, durante o período específico da pandemia da COVID 19, como recomendam a $\mathrm{CIDH}^{25}$ a $\mathrm{OEA}^{26}$ e o ILANUD $^{27}$ : (1) os Estados devem dar prioridade às pessoas historicamente excluídas ou em risco especial, como as pessoas privadas de liberdade, ${ }^{28}$ que, independentemente de sua condição pessoal, devem, todas, ser consideradas vulneráveis à contaminação $^{29}$; (2) o aprisionamento acarreta riscos para toda a população carcerária, funcionários do sistema prisional $^{30}$ e população em geral $^{31}$; e (3)

\footnotetext{
${ }^{19}$ A Organização Mundial da Saúde, em 11/03/2020, declarou pandêmica a proliferação do Covid
} 19; v. Declaração de Emergência em Saúde Pública de Importância Internacional da Organização Mundial da Saúde, em 30 de janeiro de 2020, Declaração de Emergência em Saúde Pública de Importância Nacional - ESPIN, veiculada pela Portaria no 188/GM/MS, em 4 de fevereiro de 2020, e o previsto na Lei n. 13.979, de 6 de fevereiro de 2020, que dispõe sobre as medidas para enfrentamento da emergência de saúde pública de importância internacional decorrente do novo coronavírus.

${ }^{20}$ Declaração Americana dos Direitos e Deveres do Homem, de 1948

${ }^{21}$ Convenção Americana sobre Direitos Humanos, de 1969 (Pacto de San José de Costa Rica)

${ }^{22}$ Protocolo de San Salvador - Protocolo Adicional à Convenção Americana Sobre Direitos Humanos em Matéria de Direitos Econômicos, Sociais e Culturais, de 1988

${ }^{23}$ Carta Social das Américas e seu Plano de Ação

${ }^{24} \mathrm{https}$ ://www.unfpa.org/es/el-enfoque-basado-en-los-derechos-humanos

${ }_{25} \mathrm{CIDH}$ - Comissão Interamericana de Direitos Humanos

${ }^{26}$ Organização dos Estados Americanos.

${ }^{27}$ Instituto Latino-Americano das Nações Unidas para a prevenção do Delito e Tratamento do Delinquente

${ }^{28}$ OEA - Guia Prático de Respostas Inclusivas e com enfoque de Direitos diante da Pandemia do COVID-19 nas Américas e Resolução CIDH n. 1/2020, Pandemia y Derechos Humanos en Las Américas, em 10 de abril de 2020.

${ }^{29}$ As prisões brasileiras registraram no início de junho um aumento de $800 \%$ nos casos de infecção pelo novo coronavírus em relação a maio, segundo balanço divulgado pelo CNJ (Conselho Nacional de Justiça). $1 \%$ da população carcerária brasileira; 2.351 presos haviam sido diagnosticados com covid-19 até o dia 17.06.2020, segundo o Depen; 727 era o número de casos suspeitos, ainda à espera de confirmação; 8.924 testes em presos com suspeita da doença foram realizados no país, o que representa apenas $1,2 \%$ da população carcerária.

${ }^{30}$ A pesquisa "Os agentes prisionais e a pandemia de covid-19", conduzida pelo Núcleo de Estudos da Burocracia da FGV (Fundação Getúlio Vargas) e divulgada no início de junho, mostrou que apenas 
e magistrados, orientados pelo princípio pro persona, devem reservar as prisões preventivas para casos absolutamente excepcionais, dando preferência às medidas cautelares alternativas, visando ao desencarceramento, ${ }^{32}$ como dispõem, inclusive, as Regras de Tóquio. ${ }^{33}$

Contudo, as pesquisas sobre as decisões judiciais proferidas durante o momento pandêmico desvelam que os magistrados e magistradas não

$32,6 \%$ dos agentes disseram ter recebido equipamentos de proteção individual para trabalhar e só $9,3 \%$ afirmaram que tiveram treinamento para lidar com a pandemia. O estudo ouviu 301 agentes de todo o país. Mais da metade deles $(54,8 \%)$ tiveram um colega de serviço ou um familiar infectado ou com a suspeita da doença. A grande maioria $(82,4 \%)$ declarou ter medo de contrair a covid-19 nas prisões. "Estamos há mais de um mês na pandemia, somos o braço do Estado, e o Estado não nos deu equipamento de proteção. Tive que comprar meu álcool, minha luva, minha máscara”. Agente penitenciário anônimo em entrevista conduzida por pesquisadores da FGV. Segundo os dados do CNJ, o número de servidores que trabalham em presídios que contraíram o coronavírus até junho era de 2.944. As mortes somavam 41. Segundo a pesquisa da FGV, apenas $16,3 \%$ desses profissionais se dizem preparados para atuar nas prisões no contexto de pandemia. Eles relataram aumento de estresse entre presos e funcionários e a sensação de pânico por se sentirem indefesos em relação à doença. https://www.nexojornal.com.br/expresso/2020/06/17/O-avan\%C3\%A7o-da-covid-19-naspris\%C3\%B5es.-E-a-subnotifica\%C3\%A7\%C3\%A3o-de-casos@ 2020

31 "Do exemplo chinês podemos verificar que a população carcerária será impactada diretamente pela pandemia. Noticia-se que houve contaminação de inúmeros presos (https://thediplomat.com/2020/03/cracks-in-the-system-covid-19-in-chinese -prisions) e que isso é um fato determinante para a proliferação da contaminação na própria sociedade externa aos presídios (http://theconversation.com/why-releasing-some-prisoners-is-essential-to-stop-the-spread-ofcoronavirus-133516)" (STF-HC 183584 / RJ).

${ }^{32} \mathrm{La}$ CIDH y su REDESCA instan a asegurar las perspectivas de protección integral de los derechos humanos y de la salud pública frente a la pandemia del COVID-19, Disponible en: http://www.oas.org/es/cidh/prensa/ comunicados/2020/060.asp

"As prisões na América Latina e Caribe estão quase sempre superlotadas e isso dificulta o acesso ao saneamento adequado, o que exige que se tomem medidas para reduzir a quantidade de pessoas que se encontram privadas de liberdade; isso contribuirá, induvidosamente, a reduzir o risco de situações extremas nas quais o Covid-19 causa estragos na população que, por si só, é vulnerável. O que se impõe, diante do atual cenário, é acelerar a implementação de propostas, inclusive, não são novas, mas que, agora, requer uma maior ênfase. Com efeito, o que agora há que enfatizar é a colocação em marcha de mecanismos como os que podíamos encontrar em instrumentos como as Regras Mínimas Nações Unidas sobre as Medidas não Privativas da Liberdade, as Regras de Tóquio, as quais datam de 1990, mas agora com maior celeridade, diante da pandemia. As Regras de Tóquio estabelecem medidas substitutivas ao encarceramento, e são aplicáveis tanto durante o processo quanto às pessoas sentenciadas, o que é de grande relevância, dado que na América Latina e Caribe temos, além do uso às vezes excessivo da sanção penal privativa de liberdade, populações imensas em prisão preventiva em situações absolutamente inaceitáveis, o que faz com que a quantidade de presos preventivos tenha um peso demasiado no contexto global das pessoas privadas de liberdade" (O sistema prisional em face da encruzilhada produzida pela crise provocada pelo Convid-19, 19 de Abril de 2020).

Filos. e Educ., Campinas, SP, v.12, n.2, p.1085-1125, maio/ago. 2020 - ISSN 1984-9605 
estão considerando essas normas, recomendações, regras e princípios em suas decisões.

Com efeito, por exemplo, o CADICRIM, ${ }^{34}$ que é o Centro de Apoio à Seção de Direito Criminal do Tribunal de Justiça de São Paulo, publicou, em abril de 2020, um boletim informativo, com a finalidade de auxiliar os juízes e juízas criminais paulistas, uma coletânea com vinte decisões do Tribunal de Justiça de São Paulo sobre prisões preventivas, proferidas durante a pandemia, mas, as ementas dessas decisões não fazem nenhuma referência às normas ou recomendações do sistema de direitos humanos relacionadas especificamente com a pandemia ${ }^{35}$. E a maioria dos argumentos dessas decisões contraria os paradigmas, critérios e estândares construídos pelos órgãos especializados do sistema de garantias dos direitos humanos.

\subsection{Recomendações do CNJ e do sistema internacional de proteção dos direitos humanos com relação às prisões preventivas durante a pandemia da COVID 19}

O Brasil, com $773.151^{36}$ presos, tem a terceira população carcerária, a superlotação dos presídios brasileiros, segundo o STF, compõe "um estado de coisas inconstitucional" ${ }^{\text {"37 }}$ e $33 \%$ das pessoas presas estão presas em situação de provisoriedade, ou seja, estão presas em razão da decretação de sua prisão preventiva. Mas, em São Pauto, por exemplo, das 35.000 pessoas presas preventivamente, que poderiam ser beneficiadas com o desencarceramento, se aplicadas acolhidas as recomendações e aplicadas as normas do sistema de proteção dos direitos humanos, foram beneficiadas

\footnotetext{
${ }^{34}$ CADICRIM - CENTRO DE APOIO À SEÇÃO DE DIREITO CRIMINAL. Instituído pelo Tribunal de Justiça de São Paulo, por meio da Portaria Conjunta no 9.765/2019, publicada no DJE de 26/06/2019, tem como função primordial auxiliar os Desembargadores e Juízes integrantes da Seção de Direito Criminal do Tribunal de Justiça de São Paulo em pesquisas de jurisprudência, doutrina e legislação. $O$ CADICRIM também produz materiais de apoio nos quais divulga notícias, julgamentos e alterações legislativas relevantes ao Direito Criminal.

${ }^{35}$ BOLETIM CADICRIM COVID-19 - Tribunal de Justiça de São Paulo - Julgados de Direito Criminal - Material de Apoio

${ }^{36}$ DEPEN - Departamento Penitenciário Nacional (Depen). 14.06.2020. Levantamento Nacional de Informações Penitenciárias (Infopen) de 2019. Disponível em www.depen.gov.br

${ }^{37}$ ADPF 347, STF
} 
apenas 700 , ou seja, $2 \%,{ }^{38}$ sem que essas recomendações ou parâmetros estabelecidos no concerto dos direitos humanos tenham sido considerados ou enfrentados na grande maioria das respectivas decisões..

A Organização Mundial da Saúde - OMS, em 11 de março de 2020, declarou pandêmica a proliferação do novo coronavírus ${ }^{39}$. E o CNJ Conselho Nacional de Justiça, então, editou, no 17 de março de 2020, a Recomendação n. 62, recomendando aos Tribunais, magistrados e magistradas a adoção de medidas preventivas à propagação da infecção pelo novo coronavírus no âmbito dos sistemas de justiça penal e socioeducativo, com as seguintes finalidades: I - a proteção da vida e da saúde das pessoas privadas de liberdade, dos magistrados, e de todos os servidores e agentes públicos que integram o sistema de justiça penal, prisional e socioeducativo, sobretudo daqueles que integram o grupo de risco, tais como idosos, gestantes e pessoas com doenças crônicas, imunossupressoras, respiratórias e outras comorbidades preexistentes que possam conduzir a um agravamento do estado geral de saúde a partir do contágio, com especial atenção para diabetes, tuberculose, doenças renais, HIV e coinfecções; II redução dos fatores de propagação do vírus, pela adoção de medidas sanitárias, redução de aglomerações nas unidades judiciárias, prisionais e socioeducativas, e restrição às interações físicas na realização de atos processuais; e III - garantia da continuidade da prestação jurisdicional, observando-se os direitos e garantias individuais e o devido processo legal (Res. CNJ n. 62/2020, art. $1^{\circ}$, parágrafo único).

Nessa Recomendação, o CNJ reconheceu que "a manutenção da saúde das pessoas privadas de liberdade é essencial à garantia da saúde coletiva e que um cenário de contaminação em grande escala nos sistemas prisional e socioeducativo produz impactos significativos para a segurança e a saúde pública de toda a população, extrapolando os limites internos dos

\footnotetext{
${ }^{38}$ https://www.nexojornal.com.br/expresso/2020/06/17/O-avan\%C3\%A7o-da-covid-19-naspris\%C3\%B5es.-E-a-subnotifica\%C3\%A7\%C3\%A3o-de-casos@ 2020

39 v. também Declaração de Emergência em Saúde Pública de Importância Internacional da Organização Mundial da Saúde, em 30 de janeiro de 2020, a Declaração de Emergência em Saúde Pública de Importância Nacional - ESPIN, veiculada pela Portaria no 188/GM/MS, em 4 de fevereiro de 2020, e o previsto na Lei no 13.979, de 6 de fevereiro de 2020, que dispõe sobre as medidas para enfrentamento da emergência de saúde pública de importância internacional decorrente do novo coronavírus
} 
estabelecimentos". Além disso, o CNJ também afirmou "a necessidade de estabelecer procedimentos e regras para fins de prevenção à infecção e à propagação do novo vírus particularmente em espaços de confinamento, de modo a reduzir os riscos epidemiológicos de sua transmissão e preservar a saúde de agentes públicos, pessoas privadas de liberdade e visitantes, evitando-se contaminações de grande escala que possam sobrecarregar o sistema público de saúde”. E, ainda segundo o CNJ, também não se pode olvidar "o alto índice de transmissibilidade do novo coronavírus e o agravamento significativo do risco de contágio em estabelecimentos prisionais e socioeducativos, tendo em vista fatores como a aglomeração de pessoas, a insalubridade dessas unidades, as dificuldades para garantia da observância dos procedimentos mínimos de higiene e isolamento rápido dos indivíduos sintomáticos, insuficiência de equipes de saúde, entre outros, características inerentes ao "estado de coisas inconstitucional" do sistema penitenciário brasileiro reconhecido pelo Supremo Tribunal Federal na Arguição de Descumprimento de Preceito Fundamental no 347’.

Assim, diante da necessidade de adoção de medidas desencarceradoras para minimizar os impactos da pandemia da COVID-19 e reduzir danos diante da atual situação de calamidade sanitária mundial causada por essa pandemia viral, o CNJ recomendou seja observada a máxima excepcionalidade de novas ordens de prisão preventiva (v. art. $4^{\circ}$, item III). Contudo, embora essas recomendações do CNJ sejam extremamente relevantes e oportunas, não têm elas caráter cogente e não são vinculantes, ou seja, são recomendações desprovidas de obrigatoriedade para a sua aplicação pelos magistrados e magistradas.

Foi então que a CIDH - Comissão Interamericana de Direitos Humanos editou a Resolução n. 1/2020, Pandemia y Derechos Humanos en las Américas, em 10 de abril de 2020, uma norma de aplicação obrigatória e vinculante, afirmando que, nesse momento de necessidade de adoção de medidas de emergência e contenção diante da pandemia da COVID-19, os Estados devem dar prioridade às pessoas historicamente excluídas ou em risco especial, entre as quais estão as pessoas privadas de liberdade. 
Aliás, a CIDH, nessa Resolução normativa, obrigatória e vinculante, reconhecendo que as prisões preventivas devem ser reservadas para casos excepcionais e aplicadas somente diante de absoluta imprescindibilidade, determinou que devem ser reavaliados os casos de prisão preventiva para serem identificados aqueles que comportam a substituição da privação de liberdade por outras medidas alternativas à prisão.

E não se olvide que a Declaração Americana dos Direitos e Deveres do Homem, de 1948, em seu artigo XI, e a Convenção Americana sobre Direitos Humanos (Pacto de San José de Costa Rica - 1969) garantem a todas as pessoas o direito à preservação de sua saúde por medidas sanitárias. Além disso, o Protocolo Adicional à Convenção Americana Sobre Direitos Humanos em Matéria de Direitos Econômicos, Sociais e Culturais (Protocolo De San Salvador - 1988) assegura a todas as pessoas o direito ao mais alto nível de assistência à saúde e afirma a obrigação dos Estados de reconhecer a saúde como um bem público, adotar uma série de medidas para garantir esse direito, entre as quais está a total imunização, a prevenção e o tratamento das enfermidades endêmicas, a educação da população sobre a prevenção e tratamento dos problemas de saúde e a satisfação das necessidades de saúde dos grupos de mais alto risco, o que é impossível garantir para as pessoas presas, máxime em tempos de pandemia. É por isso que a CIDH, determinou que os Estados adotem medidas especiais visando ao desencarceramento, com apego ao princípio pro persona, para que prevaleça o devido e oportuno cuidado com a população sobre qualquer outra pauta ou interesse de natureza pública ou privada. ${ }^{40}$

Ademais, a Carta Social das Américas e seu Plano de Ação dispõe que o gozo da saúde no seu grau máximo constitui um dos direitos humanos fundamentais, que o direito à saúde é uma condição fundamental para a inclusão e coesão social e que o direito desenvolvimento integral e o crescimento econômico com equidade devem ser garantidos, também, mas, que devem ser priorizados, em sua integralidade, os direitos econômicos,

40 La CIDH y su REDESCA instan a asegurar las perspectivas de protección integral de los derechos humanos $y$ de la salud pública frente a la pandemia del COVID-19." Disponible en: http://www.oas.org/es/cidh/prensa/ comunicados/2020/060.asp

Filos. e Educ., Campinas, SP, v.12, n.2, p.1085-1125, maio/ago. 2020 - ISSN 1984-9605 
sociais, culturais e ambientais, como o direito à saúde, alimentação, moradia, emprego e previdência social. ${ }^{41}$ É por isso que a OEA editou o "Guia Prático de Respostas Inclusivas e com Enfoque de Direitos diante da Pandemia da COVID-19 nas Américas", afirmando que a saúde é um direito e que essa pandemia afeta, diretamente, a todas as pessoas, mas, de modo mais profundo, as pessoas em situação de vulnerabilidade, entre as quais estão as pessoas encarceradas, afirmando o seguinte:

"As pessoas privadas de liberdade encontram-se em uma situação de maior vulnerabilidade ao contágio da COVID-19 comparadas com a população em geral dado que vivem em espaços confinados com muitas outras pessoas por períodos de tempo prolongados. $\mathrm{O}$ encarceramento propicia a propagação de enfermidades, dificulta o acesso aos serviços básicos de saúde e os cárceres constituem fator de risco para a ocorrência de calamidades. (...) A separação física e o auto isolamento dessas pessoas é praticamente impossível, assim como manter as condições de higiene e prevenção, como lavar as mãos, (...). As pessoas privadas de liberdade também enfrentam outros fatores que aumentam o risco ante a COVID19, como o de encontrar-se em piores condições de saúde e contar com um sistema imunológico debilitado devido ao estresse, má nutrição ou prevalência ou coexistência de outras enfermidades como tuberculose ou outras doenças virais sanguíneas. Experiencias passadas mostram que as prisões, cárceres e outros centros de detenção, onde as pessoas encontram-se muito próximas, podem atuar como uma fonte de infecção, amplificação e propagação de enfermidades infecciosas tanto dentro como fora dos estabelecimentos, motivo pelo qual $o$ cuidar da saúde das pessoas privadas de liberdade é amplamente considerado como uma maneira de também cuidar da saúde pública".

Assim, a OEA, no aludido documento, em seu Capítulo 8 ( $L a$ Protección de las Personas Privadas de Libertad durante la Pandemia del Covid-19), entre outras, afirma a necessidade da adoção de medidas que reduzam drasticamente a população prisional e tenham um impacto

\footnotetext{
${ }^{41}$ https://www.unfpa.org/es/el-enfoque-basado-en-los-derechos-humanos
} 
imediato na situação de superpopulação, o que exige que a privação de liberdade seja aplicada apenas como uma medida de último recurso, adotando-se, como regra, medidas alternativas à privação de liberdade para as pessoas que estão em prisão preventiva. Como se vê, o sistema de proteção dos Direitos Humanos, com força de normatividade constitucional, vinculante e obrigatória, proclama ser imprescindível a tomada de providências para realizar o desencarceramento e a drástica redução da população carcerária, observados os estândares internacionais de garantia de direitos, mas, também, para evitar a ampliação do aprisionamento, principalmente preventivo, que deve ser reservado, sobretudo nos momentos excepcionais e de emergência, apenas para casos de extrema necessidade e que estejam a exigir o aprisionamento como solução única e insubstituível.

E é preciso lembrar o que afirmou o ILANUD ${ }^{42}$ sobre a necessidade de medidas de desencarceramento e, em especial, sobre a imprescindibilidade da adoção de medida alternativas à prisão preventiva, lembrando, inclusive, as exigências das Regras de Tóquio:

"As prisões na América Latina e Caribe estão quase sempre superlotadas e isso dificulta o acesso ao saneamento adequado, o que exige que se tomem medidas para reduzir a quantidade de pessoas que se encontram privadas de liberdade; isso contribuirá, induvidosamente, a reduzir o risco de situações extremas nas quais a Covid-19 causa estragos na população que, por si só, é vulnerável. O que se impõe, diante do atual cenário, é acelerar a implementação de propostas, inclusive, não são novas, mas que, agora, requer uma maior ênfase. Com efeito, o que agora há que enfatizar é a colocação em marcha de mecanismos como os que podíamos encontrar em instrumentos como as Regras Mínimas Nações Unidas sobre as Medidas não Privativas da Liberdade, as Regras de Tóquio, as quais datam de 1990, mas agora com maior celeridade, diante da pandemia. As Regras de Tóquio estabelecem medidas substitutivas ao encarceramento, e são aplicáveis tanto durante o

\footnotetext{
${ }^{42}$ Instituto Latino-americano das Nações Unidas para a Prevenção de Delito e Tratamento de Delinquente
}

Filos. e Educ., Campinas, SP, v.12, n.2, p.1085-1125, maio/ago. 2020 - ISSN 1984-9605 
processo quanto às pessoas sentenciadas, o que é de grande relevância, dado que na América Latina e Caribe temos, além do uso às vezes excessivo da sanção penal privativa de liberdade, populações imensas em prisão preventiva em situações absolutamente inaceitáveis, o que faz com que a quantidade de presos preventivos tenha um peso demasiado no contexto global das pessoas privadas de liberdade". ${ }^{43}$

Em apertada síntese, portanto, segundo o sistema de proteção dos direitos humanos, nos momentos de emergência, como no caso da pandemia da COVID 19, os juízes e juízas, ao decidirem sobre prisões preventivas, devem observar os seguintes paradigmas normativos objetivos: (1) todas as pessoas privadas de liberdade estão em situação de vulnerabilidade, independentemente de sua condição sanitária pessoal; (2) todos os locais de aprisionamento de pessoas são locais de risco, independentemente de suas condições sanitárias e de salubridade específicas; (3) o aprisionamento representa perigo pandêmico para toda a população carcerária, para os funcionários dos estabelecimentos prisionais e para seus familiares e, também, em consequência, para a sociedade em geral; (3) a prisão preventiva somente deve ser decretada ou mantida em casos absolutamente excepcionais, quando totalmente inaplicáveis e ineficazes medidas cautelares alternativas; e (4) há de ser promovido um desencarceramento, realizando-se, especialmente, uma drástica redução do encarceramento preventivo.

E, obviamente, todos os juízes e juízas devem observar, no âmbito jurisdicional, esses estândares e paradigmas jurídicos internacionais estabelecidos no âmbito de proteção dos direitos humanos e, especificamente, para a garantia das pessoas em situação de vulnerabilidade compulsória, pois, como já decidiu a Corte Interamericana de Direitos Humanos, o sistema interamericano de direitos humanos estabelece que os Estados estão em uma posição especial de garante de todos os direitos das

${ }^{43} \mathrm{O}$ sistema prisional em face da encruzilhada produzida pela crise provocada pelo Convid-19, 19 de Abril de 2020

Filos. e Educ., Campinas, SP, v.12, n.2, p.1085-1125, maio/ago. 2020 - ISSN 1984-9605 
pessoas que estão sob a sua custódia. ${ }^{44}$ Aliás, não se olvide que não apenas o STF, mas, todos os juízes e juízas devem exercer o seu papel primacial de garantidores e garantidoras dos direitos fundamentais e da prevalência do sistema de proteção dos direitos humanos.

Todavia, nas decisões estudadas, esses paradigmas e estândares estabelecidos pelo sistema de proteção dos direitos humanos foram praticamente ignorados e, muita vez, frontalmente contrariados.

\subsection{Decisões do Tribunal de Justiça de São Paulo sobre a necessidade da prisão preventiva durante a pandemia da COVID 19.}

Com acima antecipei, o CADICRIM ${ }^{45}$ publicou, em abril de 2020, um boletim informativo, com a finalidade de auxiliar os juízes e juízas criminais de São Paulo, mas, obviamente, com repercussão em todo o território nacional, uma coletânea com vinte decisões "referenciais" do Tribunal de Justiça de São Paulo sobre prisões preventivas, proferidas durante a pandemia da COVID 19. Todavia, as ementas dessas decisões não fazem nenhuma referência às normas ou recomendações do sistema de direitos humanos relacionadas especificamente com a pandemia da COVID $19^{46}$. E a maioria dos argumentos dessas decisões contraria os paradigmas, critérios e estândares estabelecidos no concerto internacional dos direitos humanos:

\section{a. desencarceramento negado com fundamento nas condições} pessoais da pessoa presa: embora o sistema de proteção dos direitos

\footnotetext{
${ }^{44}$ Corte IDH. Caso Vera Vera y otra vs. Ecuador. Excepción Preliminar, Fondo, Reparaciones y Costas. Sentencia de 19 de mayo de 2011. Serie C No. 226, párr. 42. Véase también el Informe sobre los derechos humanos de las personas privadas de libertad en las Américas, en particular el capítulo II sobre "la posición de garante del Estado frente a las personas privadas de libertad

${ }^{45}$ CADICRIM - CENTRO DE APOIO À SEÇÃO DE DIREITO CRIMINAL. Instituído pelo Tribunal de Justiça de São Paulo, por meio da Portaria Conjunta no 9.765/2019, publicada no DJE de 26/06/2019, tem como função primordial auxiliar os Desembargadores e Juízes integrantes da Seção de Direito Criminal do Tribunal de Justiça de São Paulo em pesquisas de jurisprudência, doutrina e legislação. $O$ CADICRIM também produz materiais de apoio nos quais divulga notícias, julgamentos e alterações legislativas relevantes ao Direito Criminal.

${ }^{46}$ BOLETIM CADICRIM COVID-19 - Tribunal de Justiça de São Paulo - Julgados de Direito Criminal - Material de Apoio
}

Filos. e Educ., Campinas, SP, v.12, n.2, p.1085-1125, maio/ago. 2020 - ISSN 1984-9605 
humanos afirme que estão em situação de vulnerabilidade todas as pessoas presas, independentemente de suas condições sanitárias pessoais, a prisão preventiva foi mantida em cinco dos acórdãos publicados, os quais fundamentaram a decisão afirmando (1) que "não há comprovação de que o réu pertença a grupo de risco" (TJSP, Habeas Corpus no 205564311.2020.8.26.0000, Decisão Monocrática, j. 30/03/2020), (2) que inexiste "prova pré-constituída que demonstre incompatibilidade entre o estado de saúde do Paciente e os cuidados médicos disponíveis no estabelecimento prisional" (Habeas Corpus $\mathrm{n}^{\mathrm{o}}$ 2073763-05.2020.8.26.0000, 4 ${ }^{\mathrm{a}} \mathrm{C}, \quad \mathrm{j}$. 06/05/2020), (3) que “a Defesa não apresentou qualquer comprovação de que a sentenciado se enquadra no grupo de vulneráveis do Covid-19, tampouco a impossibilidade de receber eventual tratamento no estabelecimento prisional" (Habeas Corpus $n^{\circ}$ 205704445.2020.8.26.0000, $1^{a} \mathrm{C}$, j. 05/05/2020), (4) que "não há nos autos comprovação de que o paciente pertença a grupo de risco ou de que seja portador de alguma doença que o impeça de permanecer recolhido e de, caso necessário, receber tratamento dentro do sistema prisional" (Habeas Corpus $\mathrm{n}^{\circ} 2064452$ 87.2020.8.26.0000, $1^{\mathrm{a} C} \mathrm{C}, \mathrm{j}$. 04/05/2020) e (5) que o paciente "não integra grupo de risco" (Habeas Corpus n ${ }^{\mathrm{o}}$ 2065963-23.2020.8.26.0000, 16 ${ }^{\mathrm{a}} \mathrm{C}, \mathrm{j}$. 14/05/2020);

\section{b. desencarceramento deferido com base nas condições pessoais da} pessoa presa: em cinco acórdãos, a prisão cautelar foi revogada ou substituída por outra medida cautelar, mas, não sob o argumento da vulnerabilidade de todas as pessoas presas e, sim, considerando, individualmente, a condição de saúde de cada uma delas, afirmando-se, (1) que é desnecessária a prisão preventiva, porque "o paciente é idoso com idade avançada e problemas de saúde" (TJSP, Habeas Corpus n 2027398 87.2020.8.26.0000; 16 ${ }^{\text {a }}$; j. 23/03/2020), (2) que o paciente é portador de sinusite e rinite crônicas" (TJSP; Habeas Corpus $\mathrm{n}^{\circ}$ 204311894.2020.8.26.0000, $11^{\mathrm{a} C} \mathrm{C}$, j. 01/04/2020), (3) que é necessário “preservar a saúde do paciente (TJSP; Habeas Corpus n ${ }^{\mathrm{o}}$ 200447652.2020.8.26.0000; $16^{\mathrm{a}}$ C; j. 30/03/2020), (4) que o paciente é primário, jovem, com residência certa 
e trabalho (Habeas Corpus $\mathrm{n}^{\mathrm{o}}$ 2064459-79.2020.8.26.0000, 12a $\mathrm{C}$, j. 14/05/2020) e (5) que o paciente é portador de tuberculose e por isso se enquadra no grupo de risco da COVID-19" (Habeas Corpus $\mathrm{n}^{\circ}$ 206085513.2020.8.26.0000, $1^{\mathrm{a} C}$, j. 04/05/2020);

c. desencarceramento indeferido com base nas condições do local da prisão: apesar de não ser devida a análise específica das condições sanitárias do local do aprisionamento, como afirmado pelo sistema de proteção dos direitos humanos, a prisão preventiva foi mantida em dois acórdãos, que fundamentaram a decisão afirmando (1) que "as autoridades responsáveis pela administração penitenciária do estado vêm tomando todas as providências necessárias para a preservação da saúde da população carcerária" (Habeas Corpus $\mathrm{n}^{\mathrm{o}}$ 2058035-21.2020.8.26.0000, $3^{\mathrm{a}} \mathrm{C}, \quad \mathrm{j}$. 13/05/2020) e (2) que "as autoridades de saúde pública ainda não recomendaram o esvaziamento de estabelecimentos penais como forma de prevenir eventual disseminação do vírus" (TJSP; Habeas Corpus $n^{0}$ 205733545.2020.8.26.0000; Decisão Monocrática; j. 28/03/2020); e

\section{d. desencarceramento indeferido ou deferido sem fazimento de} qualquer referência ao sistema de proteção dos direitos humanos: os demais oito acórdãos publicados, do mesmo modo como foram fundamentados os acórdãos acima referidos, ao deferir ou indeferir o desencarceramento, os seus prolatores não fizeram nenhuma menção aos parâmetros argumentativos gizados pelo sistema de proteção dos direitos humanos especificamente para os casos de prisão preventiva durante o período pandêmico, nem desses acórdãos consta qualquer referência aos tratados, convenções, recomendações ou decisões do sistema de garantia dos direitos humanos: (1) TJSP; Habeas Corpus no 2011096-80.2020.8.26.0000; $16^{\mathrm{a}} \quad$ C; j. 30/03/2020; (2) TJSP; Habeas Corpus $\mathrm{n}^{\mathrm{o}}$ 204241214.2020.8.26.0000; Decisão Monocrática; j. 20/03/2020; (3) Habeas Corpus $n^{\circ}$ 2055497-67.2020.8.26.0000, $1^{\mathrm{a}} \mathrm{C}$, j. 27/04/2020; (4) Habeas Corpus 2061745-49.2020.8.26.0000, $7^{\mathrm{a} C}$, j. 22/05/2020; (5) Habeas

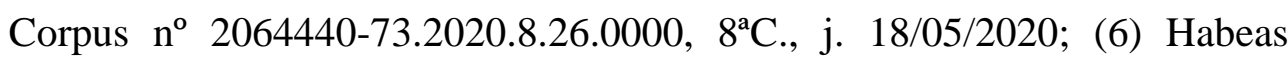
Corpus $\mathrm{n}^{\mathrm{o}}$ 2068531-12.2020.8.26.0000, rel. Francisco Orlando, 2a C, j. 
14/05/2020; (7) Habeas Corpus no 206714107.2020.8.26.0000; rel. Paulo Rossi, 12a C, j. 12/05/202; e (8) Habeas Corpus $\mathrm{n}^{\mathrm{o}}$ 205588652.2020.8.26.0000, $13^{\mathrm{a} C}$, j. 23/05/2020.

Como se vê, as decisões publicadas pelo CADICRIM, exatamente com a intenção de "auxiliar" os juízes e juízas criminais, servindo, pois, como paradigmas oficiais e norte para as decisões de primeira instância, não fazem nenhuma referência às normas ou recomendações do sistema de direitos humanos relacionadas, especificamente, com a pandemia ${ }^{47}$, nem a qualquer outra norma de proteção dos direitos humanos nem à jurisprudência da Corte Interamericana de Direitos Humanos, ignorando, olimpicamente, todo esse sistema normativo de aplicação obrigatória e vinculante incorporado ao nosso sistema jurídico-constitucional.

4.3. O não "desencarceramento drástico" no período pandêmico.

Como acima deixei consignado, o sistema de proteção dos direitos humanos, diante do enfrentamento das consequências da COVID 19, estabeleceu a necessidade premente de um drástico desencarceramento, sobretudo no que diz respeito ao aprisionamento preventivo. Lembre-se de que a OEA, bem como proclamaram outros organismos internacionais do sistema de proteção dos direitos humanos, afirmou, no Capítulo 8 ( $\mathrm{La}$ Protección de las Personas Privadas de Libertad durante la Pandemia del Covid-19) do "Guia Prático de Respostas Inclusivas e com Enfoque de Direitos diante da Pandemia da COVID-19 nas Américas", a necessidade da adoção de medidas que reduzam drasticamente a população prisional e tenham um impacto imediato na situação de superpopulação, o que está a exigir que a privação de liberdade seja aplicada apenas como uma medida de último recurso, adotando-se, como regra, medidas alternativas à privação de liberdade para as pessoas que estão em prisão preventiva.

${ }^{47}$ BOLETIM CADICRIM COVID-19 - Tribunal de Justiça de São Paulo - Julgados de Direito Criminal - Material de Apoio

Filos. e Educ., Campinas, SP, v.12, n.2, p.1085-1125, maio/ago. 2020 - ISSN 1984-9605 
Contudo, a análise dos dados que revelam a quantidade de processos com réus presos preventivos na comarca de Campinas, no Estado de São Paulo, demonstram que não se realizou, durante o período da pandemia, o drástico desencarceramento recomendado e até mesmo exigido, mas, sim, uma tímida e insuficiente diminuição do encarceramento preventivo.

PROCESSOS COM RÉUS PRESOS PREVENTIVAMENTE

\begin{tabular}{|c|c|c|c|c|c|c|c|}
\cline { 2 - 7 } \multicolumn{1}{c|}{} & \multicolumn{6}{c|}{ VARAS CRIMINAIS DE CAMPINAS/SP } \\
\hline Junho/2019 & Júri & $\begin{array}{c}\mathbf{1}^{\mathbf{a}} \\
\text { Crim }\end{array}$ & $\begin{array}{c}\mathbf{2}^{\mathbf{a}} \\
\text { Crim }\end{array}$ & $\begin{array}{c}\mathbf{3}^{\mathbf{a}} \\
\text { Crim }\end{array}$ & $\begin{array}{c}\mathbf{4}^{\mathbf{a}} \\
\text { Crim }\end{array}$ & $\begin{array}{c}\mathbf{5}^{\mathbf{a}} \\
\text { Crim }\end{array}$ & $\begin{array}{c}\mathbf{6}^{\mathbf{a}} \\
\text { Crim }\end{array}$ \\
\hline $\begin{array}{c}\text { Procs e IPs } \\
\text { (total) }\end{array}$ & 1895 & 3823 & 3341 & 4581 & 3035 & 2686 & 4087 \\
\hline $\begin{array}{c}\text { Procs e IPs } \\
\text { (presos) }\end{array}$ & 86 & 360 & 486 & 782 & 360 & 364 & 514 \\
\hline & $\mathbf{4 , 5 \%}$ & $\mathbf{9 , 4 \%}$ & $\mathbf{1 4 , 5 \%}$ & $\mathbf{1 7 , 1 \%}$ & $\mathbf{1 1 , 9 \%}$ & $\mathbf{1 3 , 6 \%}$ & $\mathbf{1 2 , 6 \%}$ \\
\hline
\end{tabular}

\begin{tabular}{|c|c|c|c|c|c|c|c|}
\hline \multirow[b]{2}{*}{$\begin{array}{l}\text { Dezembro/201 } \\
9\end{array}$} & \multicolumn{7}{|c|}{ VARAS CRIMINAIS DE CAMPINAS/SP } \\
\hline & Júri & $\begin{array}{c}\mathbf{1}^{\mathbf{a}} \\
\mathbf{C r i} \\
\mathbf{m}\end{array}$ & $\begin{array}{c}2^{\mathbf{a}} \\
\text { Crim }\end{array}$ & $\begin{array}{c}3^{\text {a }} \\
\text { Crim }\end{array}$ & $\begin{array}{c}4^{\mathrm{a}} \\
\mathrm{Cri} \\
\mathrm{m}\end{array}$ & $\begin{array}{c}5^{\mathbf{a}} \\
\text { Crim }\end{array}$ & $\begin{array}{c}6^{\mathrm{a}} \\
\text { Crim }\end{array}$ \\
\hline $\begin{array}{l}\text { Procs e IPs } \\
\quad \text { (total) }\end{array}$ & 1663 & 3699 & 2992 & 4380 & 2794 & 2585 & 2984 \\
\hline
\end{tabular}

Filos. e Educ., Campinas, SP, v.12, n.2, p.1085-1125, maio/ago. 2020 - ISSN 1984-9605 


\begin{tabular}{|c|c|c|c|c|c|c|c|}
\hline $\begin{array}{c}\text { Procs e IPs } \\
\text { (presos) }\end{array}$ & 57 & 364 & 343 & 770 & 265 & 320 & 542 \\
\hline & $\mathbf{3 , 4}$ & $\mathbf{9 , 8}$ & $\mathbf{1 1 , 5}$ & $\mathbf{1 7 , 6}$ & $\mathbf{9 , 5}$ & $\mathbf{1 2 , 4}$ & $\mathbf{1 3 , 6}$ \\
& $\mathbf{\%}$ & $\mathbf{\%}$ & $\mathbf{\%}$ & $\mathbf{\%}$ & $\mathbf{\%}$ & $\mathbf{\%}$ & $\mathbf{\%}$ \\
\hline
\end{tabular}

\begin{tabular}{|c|c|c|c|c|c|c|c|}
\cline { 2 - 7 } \multicolumn{1}{c|}{} & \multicolumn{7}{c|}{ VARAS CRIMINAIS DE CAMPINAS/SP } \\
\hline Janeiro/2019 & Júri & $\begin{array}{c}\mathbf{1}^{\mathbf{a}} \\
\text { Crim }\end{array}$ & $\begin{array}{c}\mathbf{2}^{\mathbf{a}} \\
\text { Crim }\end{array}$ & $\begin{array}{c}\mathbf{3}^{\mathbf{a}} \\
\text { Crim }\end{array}$ & $\begin{array}{c}\mathbf{4}^{\mathbf{a}} \\
\text { Crim }\end{array}$ & $\begin{array}{c}\mathbf{5}^{\mathbf{a}} \\
\text { Crim }\end{array}$ & $\begin{array}{c}\mathbf{6}^{\mathbf{a}} \\
\text { Crim }\end{array}$ \\
\hline $\begin{array}{c}\text { Procs e IPs } \\
\text { (total) }\end{array}$ & 1628 & 3709 & 2896 & 4291 & 2752 & 2590 & 4002 \\
\hline $\begin{array}{c}\text { Procs e IPs } \\
\text { (presos) }\end{array}$ & 53 & 368 & 313 & 718 & 240 & 332 & 541 \\
\hline & $\mathbf{3 , 3 \%}$ & $\mathbf{9 , 9 \%}$ & $\mathbf{1 0 , 8 \%}$ & $\mathbf{1 6 , 7 \%}$ & $\mathbf{8 , 7 \%}$ & $\mathbf{1 2 , 8 \%}$ & $\mathbf{1 3 , 5 \%}$ \\
\hline
\end{tabular}

\begin{tabular}{|c|c|c|c|c|c|c|c|}
\cline { 2 - 8 } \multicolumn{1}{c|}{} & \multicolumn{7}{c|}{ VARAS CRIMINAIS DE CAMPINAS/SP } \\
\hline Junho/2020 & Júri & $\mathbf{1}^{\text {a }}$ Crim & $\mathbf{2}^{\text {a Crim }}$ & $\mathbf{3}^{\text {a }}$ Crim & $\mathbf{4}^{\text {a }}$ Crim & $\mathbf{5}^{\text {a }}$ Crim & $\begin{array}{c}\mathbf{6}^{\mathbf{a}} \\
\text { Crim }\end{array}$ \\
\hline $\begin{array}{c}\text { Procs e IPs } \\
\text { (total) }\end{array}$ & 1586 & 3753 & 2859 & 3924 & 2871 & 2729 & 3990 \\
\hline $\begin{array}{c}\text { Procs e IPs } \\
\text { (presos) }\end{array}$ & 47 & 345 & 253 & 636 & 246 & 386 & 475 \\
\hline & $\mathbf{3 , 0 \%}$ & $\mathbf{9 , 2 \%}$ & $\mathbf{8 , 8 \%}$ & $\mathbf{1 6 , 2 \%}$ & $\mathbf{8 , 6 \%}$ & $\mathbf{1 4 , 1 \%}$ & $\mathbf{1 1 , 9 \%}$ \\
\hline
\end{tabular}

Com o se vê nitidamente, analisando-se a quantidade de processos e inquéritos policiais com pessoas presas, computando-se o período de junho de 2019 a junho de 2020, nas varas com competência criminal em 
Campinas $^{48}$, constata-se que houve uma redução de apenas $1,59 \%$, o que, à evidência, não pode ser considerado um "drástico desencarceramento". E, se for considerado o período de janeiro de 2020 a junho de 2020, que abrange mais especificamente o período da pandemia, a redução do encarceramento é ainda menor, ou seja, é de apenas $0,73 \%$.

Esses dados demonstram que, nos processos criminais pesquisados, não foi considerado o posicionamento nem as exigências do sistema internacional de proteção dos direitos humanos, que afirmou a necessidade de uma drástica redução da população prisional, o que impediu a ocorrência do desejado impacto imediato na situação de superpopulação, pois, não houve aplicação da privação de liberdade provisória "apenas como uma medida de último recurso" nem foram adotadas, como regra, medidas alternativas à privação de liberdade para as pessoas que estão em prisão preventiva.

Em suma, esses dados revelaram que os juízes e juízas, na análise dos processos com réus presos, não consideraram, em suas decisões, o posicionamento, as normas, as recomendações, os princípios, os paradigmas estabelecidos pelo sistema de proteção de direitos humanos.

\section{CONCLUSÃO}

A opção constitucional pela prevalência da dignidade humana e dos direitos humanos implica a configuração normativa da sociabilidade de um Estado de Direito, Social e Humanista. Como dispõem o $\operatorname{artigo} 1^{\circ}$ da Declaração Universal dos Direitos Humanos, o item 2 do artigo $1^{\circ}$ da Convenção Americana dos Direitos Humanos e os artigos $4^{\circ}$ e $5^{\circ}$, caput e $\S$ $2^{\circ}$ da Constituição Federal de 1988, toda pessoa é um ser humano. E, como adverte ZAFFARONI (2015), em razão dessa norma, "todo ser humano deve ser considerado e tratado como pessoa", o que impõe a todos,

\footnotetext{
${ }^{48}$ Foram incluídas nessa pesquisa, da comarca de Campinas/SP: Vara do Júri, 1ª Vara Criminal do

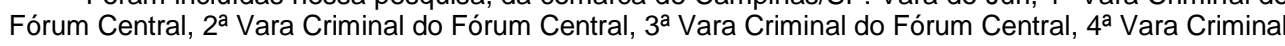
do Fórum Central, 5 ${ }^{\mathrm{a}}$ Vara Criminal do Fórum Central e $6^{\mathrm{a}}$ Vara Criminal do Fórum Central. Não foram considerados os dados das Varas do Foro Regional da Vila Mimosa nem da Vara do Juizado Especial Criminal.
} 
sobretudo aos juízes e juízas, "o dever de considerar juridicamente única a espécie humana", garantindo a todas as pessoas, indistintamente, a plenitude dos direitos humanos sob a égide de um direito que há de ser humano também, considerada, especialmente, a dinâmica da realidade social, seu movimento histórico e a sua constituição decorrente de suas relações materiais e culturais.

Os juízes e juízas, hoje, no Brasil, não têm mais nenhum compromisso com a mantença dos interesses de classes sociais beneficiadas por um modelo agrário-comercial exportador dependente, como nos tempos coloniais, imperiais ou da gênese republicana. Não têm que garantir as condições de dominação de um império mercantil salvacionista, nem a sujeição à catequese ou à aculturação. Não têm que assegurar a prevalência do patriarcado nem as bases econômicas e materiais do racismo estrutural, da escravidão, do latifúndio e da exploração do trabalho. Também não têm mais nenhum compromisso com a mantença dos privilégios do processo de estruturação do modelo nacional-desenvolvimentista baseado na industrialização nem com qualquer projeto iluministas de implantação de modelos liberais de desenvolvimento econômico vinculado à mantença do modelo de concentração da riqueza e, descompromissado com a justiça distributiva, produtor de exclusão e marginalização. Tampouco têm compromisso com os interesses econômicos ou políticos que embalaram e sustentaram o regime militar e a sujeição da democracia à ditadura e à ideologia de extermínio do estado social dos direitos sociais.

Têm, sim, os juízes e as juízas, por força da normatividade ética dos princípios constitucionais, um solene e indeclinável compromisso com o ethos de uma ordem jurídica, social e política embasada na dignidade humana. Têm um compromisso irrenunciável com prevalência dos direitos humanos. E esse compromisso implica uma atuação jurisdicional inspirada por princípios democrático e pela preeminência dos direitos humanos, o que exige, na práxis da jurisdição, a superação dos paradigmas que sustentam uma cultura jurídica tradicional, excludente e autoritária, embasada em 
privilégios, preconceitos e discriminação. Daí a preocupação com a verificação, na pesquisa em análise, da eficácia da formação de magistradas e magistrados brasileiros no campo epistemológico, ético e político do sistema de proteção dos direitos humanos.

$\mathrm{E}$, diante dos resultados que as pesquisas começam a desvelar na concretude dos dados que estão sendo coletados, as escolas judiciais e de magistratura têm o dever de prosseguir, intensificar e ampliar o projeto de formação dos juízes e juízas com embasamento primacial na ética e no humanismo, com consciente compromisso com a humanização e hominização dos magistrados e magistradas, não para conservar ou reproduzir as práticas sociais dominantes, mas, sim, "para superar e transformar as práticas sociais usuais, abrindo espaços para novas hegemonias a serem amiúde conquistadas pela luta política e pela materialidade cultural", sob o arnês principiológico de um Estado de Direito, Social e Humanista.

Como ensina Cesar Nunes (2019), "ao intentar superar a tradição autoritária e a inspiração tecnicista de sua identidade tradicional, o agente jurídico está convocado a construir bases de uma cidadania emancipatória: construtiva, participativa, criadora, democrática e integradora”. A efetivação do projeto constitucional de prevalência da dignidade e dos direitos humanos exige das Escolas judiciais e da magistratura, como instituições formadoras e emancipatórias, no espectro de uma plataforma ética e política, um acendrado compromisso com a formação baseada na igualdade, na solidariedade e no reconhecimento e garantia da diversidade.

\section{REFERÊNCIAS BIBLIOGRÁFICAS}

BRASIL. Constituição (1988). Constituição da República Federativa do Brasil. Brasília, DF: Congresso Nacional, 1988. 
BRASIL. Declaração de Emergência em Saúde Pública de Importância Nacional - ESPIN, veiculada pela Portaria no 188/GM/MS, em 4 de fevereiro de 2020.

BRASIL. Lei n. 13.979, de 6 de fevereiro de 2020, que dispõe sobre as medidas para enfrentamento da emergência de saúde pública de importância internacional decorrente do novo coronavírus.

BRASIL. Resolução/ENFAM n.2, de 8 de junho de 2016, que dispõe sobre os programas para a formação e o aperfeiçoamento de magistrados e regulamenta os cursos oficiais para o ingresso, a formação inicial e o aperfeiçoamento de magistrados e de formadores. Brasília, DF: ENFAM Escola Nacional de Formação e Aperfeiçoamento de Magistrados Ministro Sálvio de Figueiredo Teixeira, 2016.

DALARI, Dalmo de Abreu. O poder dos juízes, Saraiva, São Paulo, 1996.

DEPEN - Departamento Penitenciário Nacional (Depen). 14.06.2020. Levantamento Nacional de Informações Penitenciárias (Infopen) de 2019. Disponível em www.depen.gov.br

FAUNDES, Aníbal. DUARTE, Graciana Alves. TORRES, José Henrique Rodrigues. Aborto induzido: Opinião e Conduta de Magistrados Brasileiros. RELATÓRIO TÉCNICO FINAL. CEMICAMP, Campinas, Março, 2007

MAZZUOLI, Valério de Oliveira. O controle jurisdicional da convencionalidade, Editora Revista dos Tribunais, São Paulo, 2009.

NUNES, Cesar Aparecido. Direitos Humanos: Educação e Democracia, Capítulo 2, Educação em Direitos Humanos no Brasil Atual: fundamentos políticos e práticas pedagógicas emancipatórias possíveis, Ed. Brasílica, Campinas/SP, 2019. 
NUNES, Cesar Augusto. Direitos Humanos: Educação e Democracia, Capítulo 1, Direito. Direitos Humanos e Educação: do Direito à Educação Proclamado à Deontologia Social de um Paradigma Epistemológico e Político Emancipatório no Brasil. Ed. Brasílica, Campinas/SP, 2019.

OEA. Carta Social das Américas e seu Plano de Ação, 1988.

OEA. Convenção Americana sobre Direitos Humanos, Pacto de San José de Costa Rica, 1969.

OEA. Declaração Americana dos Direitos e Deveres do Homem, 1948

OEA. Guia Prático de Respostas Inclusivas e com enfoque de Direitos diante da Pandemia do COVID-19 nas Américas, 2020.

OEA. Protocolo de San Salvador - Protocolo Adicional à Convenção Americana Sobre Direitos Humanos em Matéria de Direitos Econômicos, Sociais e Culturais, 1988.

OEA. Resolução CIDH n. 1/2020, Pandemia y Derechos Humanos en Las Américas, em 10 de abril de 2020.

OEA. La CIDH y su REDESCA instan a asegurar las perspectivas de protección integral de los derechos humanos y de la salud pública frente a la pandemia del COVID-19, Disponible en:

http://www.oas.org/es/cidh/prensa/ comunicados/2020/060.asp

OMS. Declaração de Emergência em Saúde Pública de Importância Internacional da Organização Mundial da Saúde, em 30 de janeiro de 2020.

PIOVESAN, Flavia. Direitos Humanos e o Direito Constitucional Internacional, Ed. Max Limonad, São Paulo, 1996.

SARLET, Ingo Wolfgang. Comentários à Constituição do Brasil, Editora Saraiva, Almedina e IDD, São Paulo, 2013.

TJSP. BOLETIM CADICRIM COVID-19 - Tribunal de Justiça de São Paulo - Julgados de Direito Criminal - Material de Apoio, 2020. 
ZAFFARONI, Eugenio Raúl. Ensaio Introdutório. Direito Penal Humano ou Inumano? Rev. secr. Trib. perm. revis. Año 3, $\mathrm{N}^{\circ}$ 6; agosto 2015; p. 27-47. ISSN 2304-7887 (n línea) ISSN 2307-5163 (impreso) DOI: http://dx.doi.org/10.16890/rstpr.a3.n6.27

Submetido em: $23 / 08 / 2020$

Aceito em: $27 / 08 / 2020$

Publicado em: 30/08/2020 